University of South Florida

DIGITAL COMMONS

@ UNIVERSITY OF SOUTH FLORIDA
Digital Commons @ University of

South Florida

$11-2-2018$

\title{
CUTR Transportation Webcast Series
}

CUTR

Follow this and additional works at: https://digitalcommons.usf.edu/cutr_nctr

\section{Recommended Citation}

"CUTR Transportation Webcast Series," National Center for Transit Research (NCTR) Report No. CUTRNCTR-RR-2018-11, Center for Urban Transportation Research, University of South Florida, 2018.

DOI: https://doi.org/10.5038/CUTR-NCTR-RR-2018-11

Available at: https://scholarcommons.usf.edu/cutr_nctr/14

This Technical Report is brought to you for free and open access by the National Center for Transit Research (NCTR) Archive (2000-2020) at Digital Commons @ University of South Florida. It has been accepted for inclusion in Research Reports by an authorized administrator of Digital Commons @ University of South Florida. For more information, please contact digitalcommons@usf.edu. 
Final Report CUTR-2020-07

\title{
CUTR Transportation Webcast Series
}

\author{
Project Number \\ 79063-01 \\ Prepared For \\ National Center for Transit Research \\ USF Center for Urban Transportation Research
}

Prepared by

Stephanie Lewis, M.Ed.

July 2020

The contents of this report reflect the views of the authors, who are responsible for the facts and the accuracy of the information presented herein. This document is disseminated under the sponsorship of the U.S. Department of Transportation's University Transportation Centers Program, in the interest of information exchange. The U.S. Government assumes no liability for the contents or use thereof. 


\section{Disclaimer}

The contents of this report reflect the views of the authors, who are responsible for the facts and the accuracy of the information presented herein. This document is disseminated under the sponsorship of the U.S. Department of Transportation's University Transportation Centers Program, in the interest of information exchange. The U.S. Government assumes no liability for the contents or use thereof.

This work was supported by the National Center for Transit Research, a program of the Center for Urban Transportation Research at the University of South Florida and funded by the U.S. Department of Transportation. 


\section{Technical Report Documentation Page}

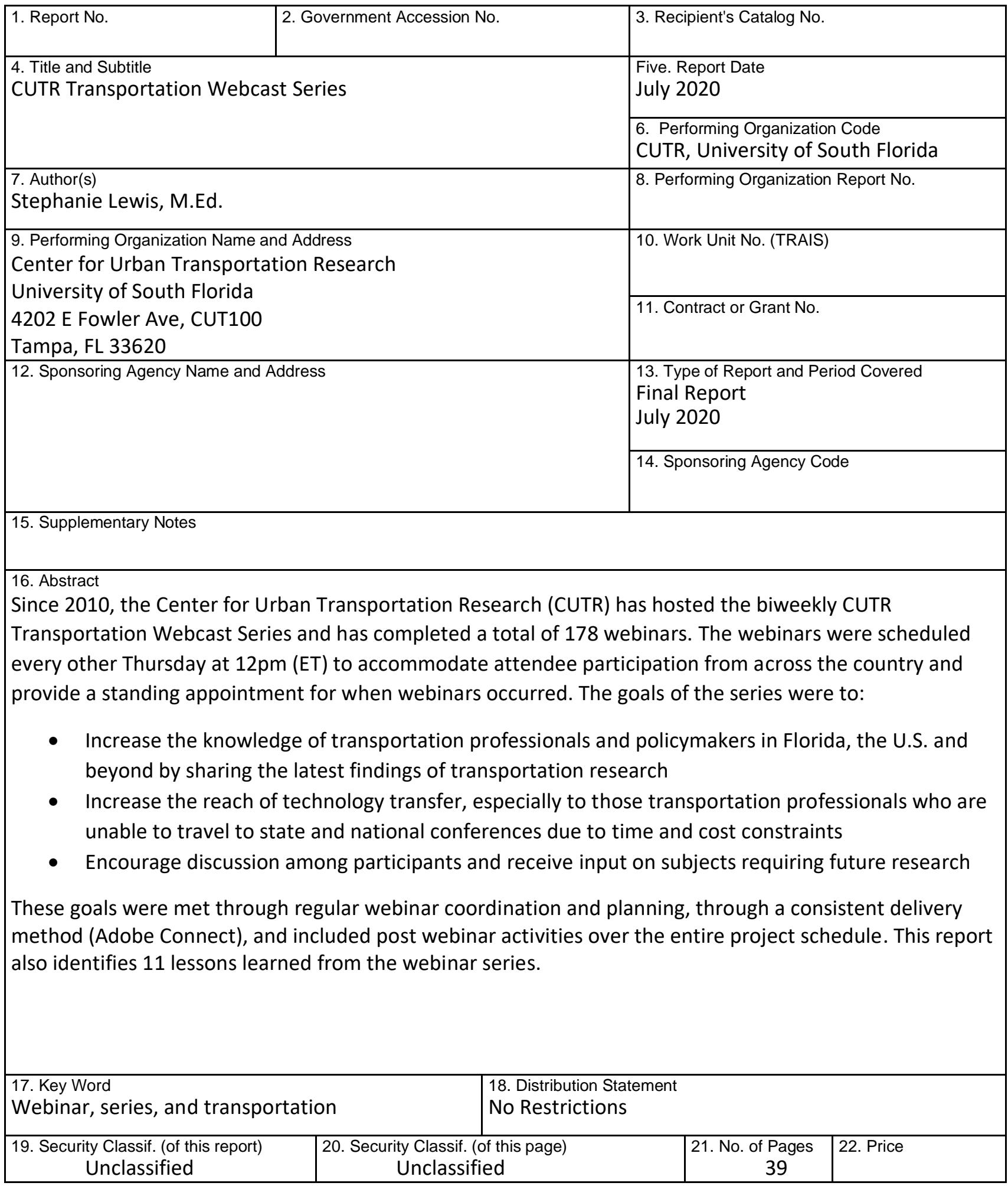




\section{Acknowledgements}

The author extends their sincere thanks to all the presenters that took their time to present each webinar represented in this report. 


\section{Table of Contents}

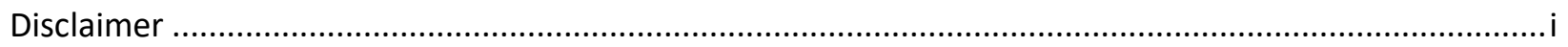

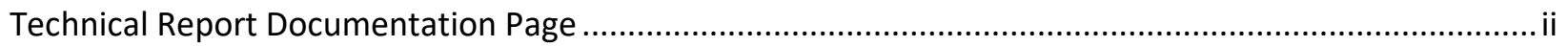

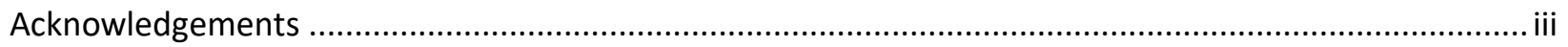

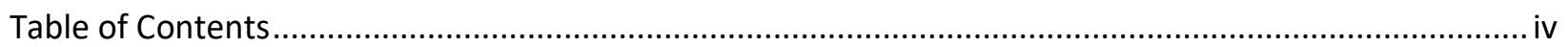

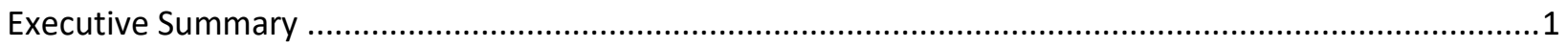

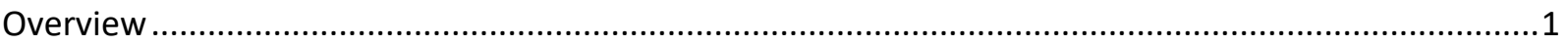

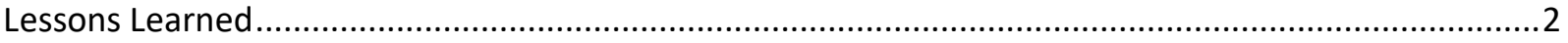

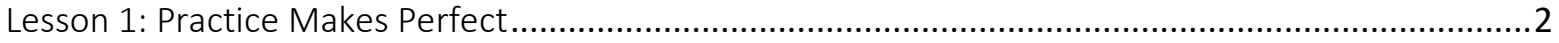

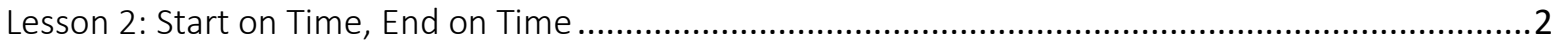

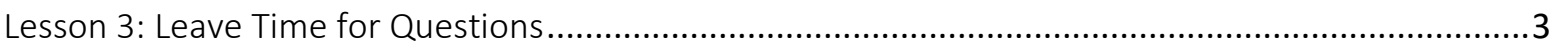

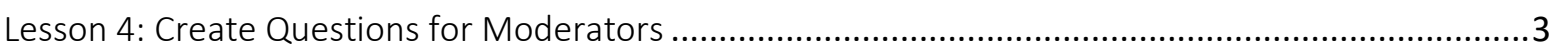

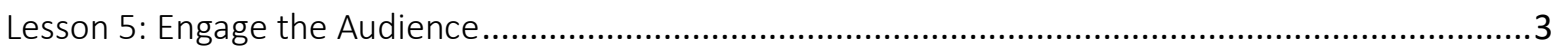

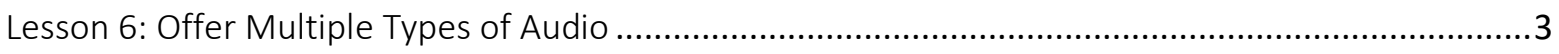

Lesson 7: Obtain Webinar Content at Least 24-48 Hours in Advance ...............................................3

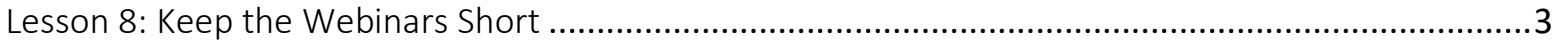

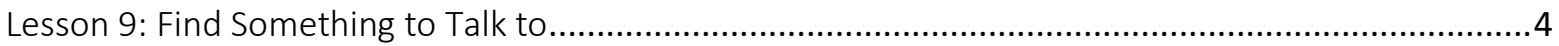

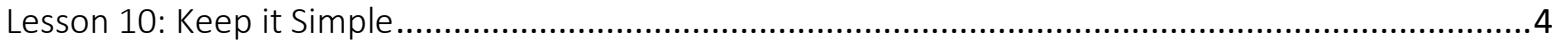

Lesson 11: Whoever Comes Are the Right People .......................................................................

Appendix A: 2018 to 2020 CUTR Transportation Webcast Series Webinars ............................................

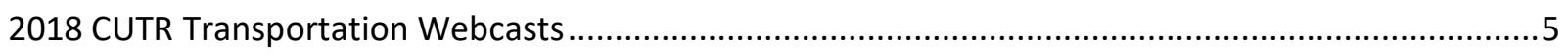

Trends in Travel Behavior and Transit Ridership .......................................................................

Understanding the Effects of Demographic and Socio-Economic Factors on Public Transit Ridership

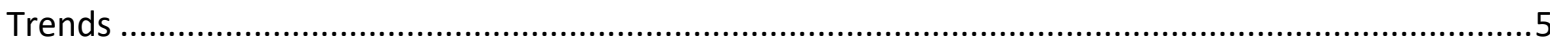

Lies, Damned Lies, AV's, Shared Mobility, and Urban Transit Futures ............................................

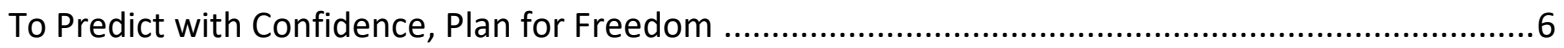

Performance-Based Management and Operations of Transportation Systems: Curriculum Concepts

Airport Clean Vehicle Policies and Practices …..............................................................................

Does the Future of Mobility Depend on Public Transportation? ..................................................

Road Rage: Countering Vehicular Weaponization Through Urban Transportation Design Strategies.8

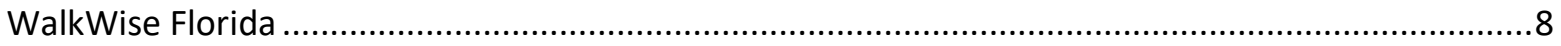

Transit in the 2000s: Where Does It Stand and Where Is It Headed?............................................... 
Overview of the Transit Capacity and Quality of Service Manual, 3rd Edition

Is It Time for a Transit Renaissance? Navigating Travel Behavior, Technology, and Business Model

Shifts in a Brave New World

Autonomous Vehicles: An Empirical Assessment of Consumers' Perceptions, Intended Adoption, and Impacts on Household Vehicle Ownership.

Operations and Planning for Connected Autonomous Vehicles: From Trajectory Control to Capacity

Analysis

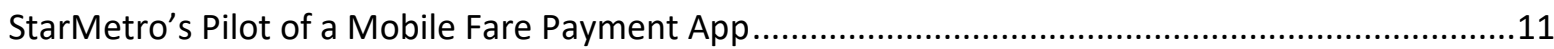

Motorcycle Safety Programs Using Public Health Approach..........................................................11

The Role of Public Transportation during a State of Emergency Declaration due to Natural Disasters

Media Framing of Fatal Bicyclist Crashes in Hillsborough County: A Critical Discourse Analysis .......12

Building an Alternative Fuel Bus Program: Funding Opportunities and Best Practices for Transit

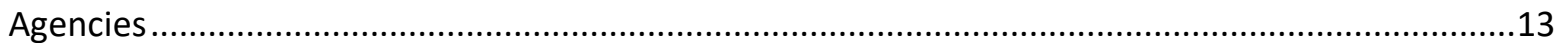

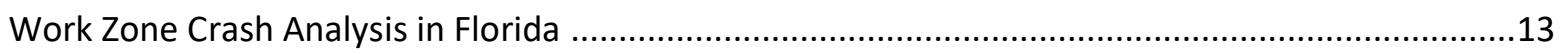

Understanding Florida Transit Ridership Declines and How We Can Respond ..............................14

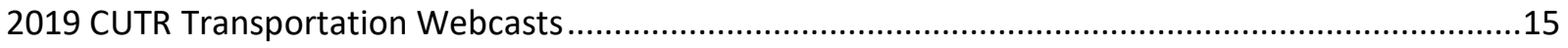

Development of Statewide Guidelines for Implementing Leading Pedestrian Intervals in Florida ....15

Urban Roadway Facility Conversion with the Predictive Safety Assessment Tool: An Application of

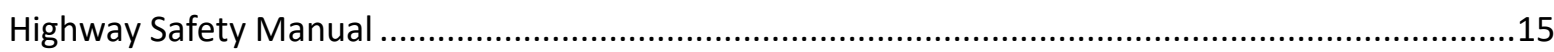

Control of Connected Autonomous Vehicles in Mixed Traffic: Modeling and Field Experiments......16

Transit Stigma \& Social Equity: What Transportation Administrators Say They Are Doing About It..16

Development of Effective Truck Route Signing Program ...........................................................17

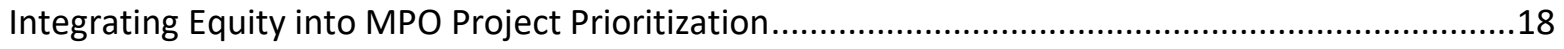

Attracting and Retaining Women in the Transportation Industry ..............................................18

How Transit Agencies Implement Best Practice Strategies in Complementary ADA Paratransit

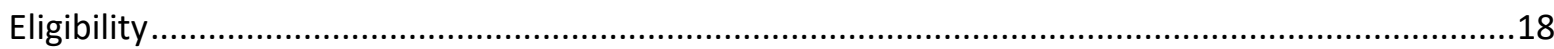

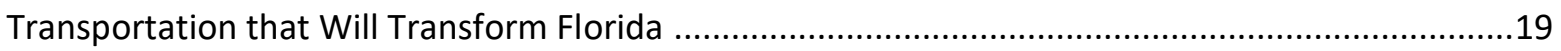

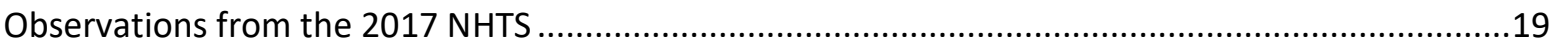

Shared (Smart) Mobility, MaaS and Public Transport - A new Future! ...........................................20

Transit and Livability: Results from the National Community Livability Survey................................20

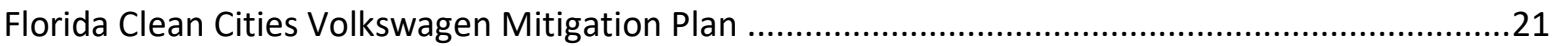

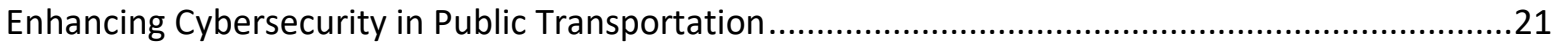

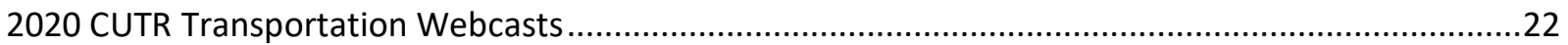


Smartphone Based Connected Bicycle Prototype Development for Sustainable Multimodal

Transportation System

The Healthy Buddy Program: Addressing Immobility in Transportation-Disadvantaged Older Adults

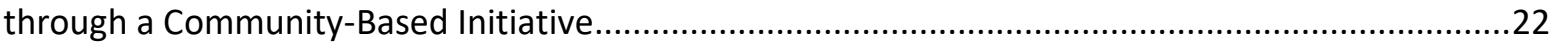

Florida's Public Transit and Women's Safety - Real and Perceived Concerns....................................22

Campus Automated Shuttle Service Deployment Initiative ..........................................................23

Improving the Quality and Cost Effectiveness of Multimodal Travel Behavior Data Collection.........24

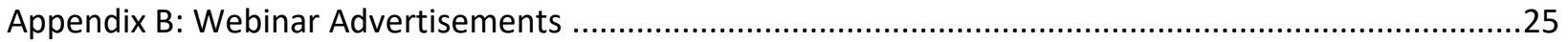

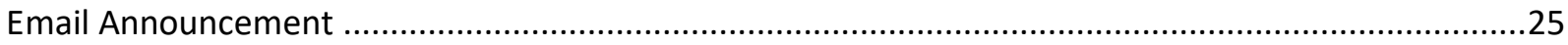

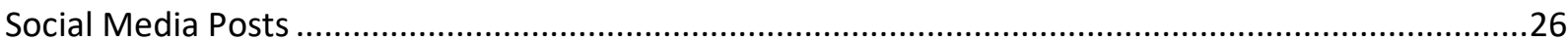

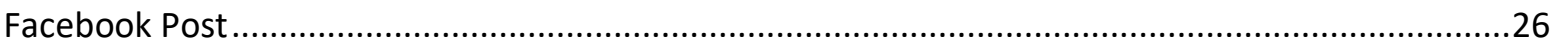

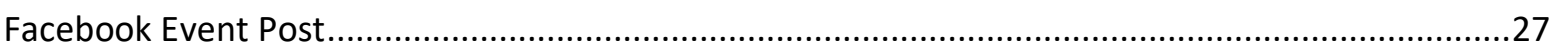

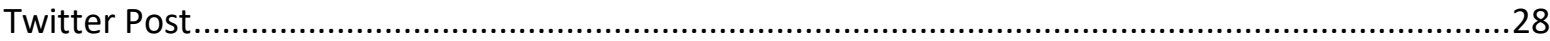

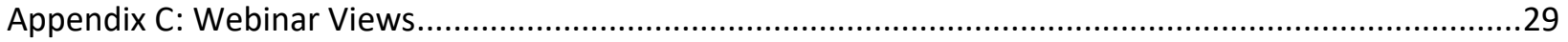




\section{Executive Summary}

\section{Overview}

Since 2010, the Center for Urban Transportation Research (CUTR) has hosted the biweekly CUTR Transportation Webcast Series and completed a total of 178 webinars. During the first five years, CUTR utilized Microsoft LiveMeeting to host the webinar series and, when the program reached an end, a license was purchased to broadcast all webinars using Adobe Connect.

The webinars were scheduled every other Thursday at $12 \mathrm{pm}$ (ET) to accommodate attendee participation from across the country and provide a standing appointment for when webinars occurred. The goals of the series were to:

- Increase the knowledge of transportation professionals and policymakers in Florida, the U.S. and beyond by sharing the latest findings of transportation research

- Increase the reach of technology transfer, especially to those transportation professionals who are unable to travel to state and national conferences due to time and cost constraints

- Encourage discussion among participants and receive input on subjects requiring future research

Webinar series presenters included those from private industry; students, researchers, and faculty members from CUTR; and university faculty and staff from around the globe. While most of the presentations were based in the United States, we did coordinate a presentation from Australia. The webinars provided the presenters an opportunity to share completed research and best practice strategies on topics in all areas of transportation. Additional topics were selected from completed National Center for Transit Research (NCTR) reports and Journal of Public Transportation (JPT) articles. Several topics included:

- Travel trends and transit ridership

- Automated vehicles

- Airport clean vehicles

- Vehicular weaponization

- Pedestrian safety

- Future of transportation

- Mobile fare payments

- Motorcycle safety

- Public transportation during states of emergency

- Alternative fuels

- Truck route signage

- Attracting and retaining women in transportation

- Paratransit eligibility

- Mobility as a Service (MaaS)

- Cybersecurity in public transportation

- Connected bicycle prototype 
A complete list of all webinars completed during the 2018 to 2020 contract period are provided in Appendix A.

Several outreach methods were used to promote the series. All sessions were advertised on the dedicated CUTR Transportation Webcast dedicated webpage (www.cutr.usf.edu/webcast/), updated as new webinars were scheduled. Additionally, the schedule was advertised on CUTR's Facebook, Twitter, and LinkedIn accounts (example social media posts are provided in Appendix B). Facebook Event Posts were scheduled in advance while the individual post for each webinar was scheduled to publish 1 hour in advance. Each advertisement included the title of the webinar, the headshot of the presenter, elements of the webinar series banner, and date and time. Lastly, a snapshot of upcoming webinars was highlighted at the beginning of each webinar presentation with a full advertisement for the next scheduled webinar in the closing slides.

The following items were collected for each session:

- Session title and description

- Short biography for each presenter

- Headshot for each presenter

- 3 or 4 ready-to-ask questions for the moderator to draw from while waiting for attendees to pose questions

- Final PowerPoint

One of the greatest benefits of utilizing webinars as a technology transfer tool is the ability to reach an audience in either a live or recorded session. During 2018 to 2020 series, 40 webinars were completed with a total of at least 1,700 people attending the live event. A complete list of views by webinar session is provided in Appendix C. The total budget for this project was $\$ 54,771$, which makes the cost of each webinar to be $\$ 32.22$ per attendee and $\$ 1,369$ per webinar with most of the costs related to labor and university indirect. If the 3,733 attendees who viewed the recordings of webinar presentations are included in this total, the cost for each webinar was $\$ 10.01$ per attendee.

\section{Lessons Learned}

Conducting the series of 40 webinars revealed several learned lessons.

\section{Lesson 1: Practice Makes Perfect}

A technical orientation session with the presenters should be conducted to ensures they resolve connection issues preemptively and are familiar with the webinar flow. If there are multiple presenters during a webinar a full-dress rehearsal should be completed with all speakers. When you have many presenters, it helps to ensure each presenter has adequate time for their portion of the presentation this prevents some presenters from being rushed if they are scheduled to present last.

\section{Lesson 2: Start on Time, End on Time}

When scheduling webinars, organizers should understand many attendees will have other meetings or conference calls. In order to be respectful of others, if a presentation goes beyond the designated time, provide an optional proper ending so the attendees have an opportunity to disconnect. This also helps to make sure the attendees have an opportunity to complete a post session evaluation. 


\section{Lesson 3: Leave Time for Questions}

If the presenters know what to expect during a webinar, they can plan their session accordingly to leave adequate time for questions. It is recommended the presenters leave 10-15 minutes for questions. Depending on the topic, there may be an opportunity to stop in the middle for questions, but midpresentation question time should be minimized for schedule adherence. If there are still questions in the $Q \& A$ window at the webinar conclusion, the questions can be sent to the presenters and responses can be posted in the webinar recording.

\section{Lesson 4: Create Questions for Moderators}

During the Q\&A portion of the webinar, it is recommended to have several pre-prepared questions for the moderator to use in the event there are no initial questions from the audience. If no questions are planned for the Q\&A section, there can be an awkward silence of transition between the presentation and the questions. If there are several questions already provided the audience has an opportunity to type their questions. These questions can be used if necessary but may be disregarded if participants are engaged in the $Q \& A$ session.

\section{Lesson 5: Engage the Audience}

To keep the audience engaged in a presentation, it is good practice to utilize poll questions to test the audience's knowledge or gain audience feedback on a subject. This gives the presenter an opportunity to gauge the topics covered. During a webinar, audience members may be logged into the webinar, but are answering emails or completing other work. Poll questions help maintain audience engagement.

\section{Lesson 6: Offer Multiple Types of Audio}

Audio during a webinar can be offered either via computer audio (VolP) or by telephone. An attendee might not be able to log in to view the presentation, but they might be able to listen on the phone. Also, having multiple audio options helps the presenters if they experience an internet outage. The phone can serve as a backup.

\section{Lesson 7: Obtain Webinar Content at Least 24-48 Hours in Advance}

It is a good practice to have presenters provide slides and webinar content to the organizer 24-48 hours in advance to test problems that may a function of content (embedded videos, image sizes, etc.). If content needs to be uploaded to the platform, sometimes formatting requires invested time. If utilizing screen sharing with some webinar platforms the transitions between speakers can cause awkward transitions. At the beginning of the webinar, it is a good practice to provide a brief overview of the webinar platform to familiarize attendees with the platform features. The ability to upload the slides ahead of time provides the hosts the ability to add these additional familiarization slides at the beginning of the presentation.

\section{Lesson 8: Keep the Webinars Short}

The length of a webinar can affect audience engagement. Currently, with so many webinars occurring, organizers and presenters should consider the time required to transfer content knowledge and what can be done to make their webinar more appealing to their intended audience. Participants might be able to attend a brief 30-minute webinar rather than a 60- to 90-minute webinar. All the CUTR Transportation Webcasts are scheduled for 60 minutes, but presenters were told to take as much time as they needed - if the content only filled 20 minutes with ten minutes for $Q \& A$, that still worked effectively. Webinar coordinators must be flexible when working with the presenters. 


\section{Lesson 9: Find Something to Talk to}

One method that worked helped webinar presenters feel comfortable and confident in their delivery was finding something within their delivery setting to "talk to," preferably with eyes (such as a photo of family or friends). This strategy makes the presenter feel their audience is listening.

\section{Lesson 10: Keep it Simple}

The slides should project a simple story - short bullets and simplified graphs and charts with basic information, while the presenter expands the story. During a webinar something should change on the slide about every 10 seconds. A simple solution would be to have the presenter utilize the "appear" PowerPoint transition, to prevent the audience from reading ahead.

\section{Lesson 11: Whoever Comes Are the Right People}

While it is tempting to measure success based on large audience numbers, webinars should not be assessed solely on such advertising metrics like reach. There are many webinar topics that appeal to niche segments of the transportation community but are no less valuable to those audiences. A wide range of topics enlarges the tent at attract a more diverse group of participants.

If organizers take time to plan for the upcoming sessions by making their presenters feel comfortable with the software platform and effectively engage the audience, the webinar will be an enjoyable experience for those in attendance. 


\section{Appendix A: 2018 to 2020 CUTR Transportation Webcast Series Webinars}

\section{CUTR Transportation Webcasts}

Trends in Travel Behavior and Transit Ridership

March 29, 2018

This webinar featured Dr. Steve Polzin sharing new information on travel trends with emphasis on transit ridership. Travel trends through calendar year 2017 will be presented with interpretation and observations on causal factors and future implications will be shared. Economic, demographic and technological trends are changing travel behavior in ways that require transportation stakeholders to adapt plans and strategies to respond to changing conditions.

Presenter: Steven Polzin, Ph.D., Program Director, Mobility Policy Research, Center for Urban Transportation Research

Recording and Handout: https://www.cutr.usf.edu/2018/03/cutr-webcast-trends-in-travel-behaviorand-transit-ridership/

Understanding the Effects of Demographic and Socio-Economic Factors on Public Transit Ridership Trends

April 12, 2018

This webinar featured Kurt Lehmann sharing his findings on key demographic factors that influence transit ridership. Kurt will discuss the general trends of U.S. transit ridership and per capita ridership in recent decades and then discuss the correlative effect each factor has had on the observed trend. Demographics are always changing and understanding how those changes affect transit ridership propensity will help transit operators and agency decision-makers as they amend their service to adapt most effectively.

Presenter: Kurt Lehmann, Graduate Research Assistant, Center for Urban Transportation Research

Recording and Handout: https://www.cutr.usf.edu/2018/04/cutr-webcast-socio-economic-factorsridership-trends/

\section{Lies, Damned Lies, AV's, Shared Mobility, and Urban Transit Futures}

April 18, 2018

This presentation outlined the arguments in Professor Curries paper published in the recent special issue of the Journal of Public Transportation on the future of public transportation. This paper aims to explore the future of public transportation, but it also aims to challenge and "derail" what current common thinking is on transport futures. It starts with an outline of a rather unusual approach that will use "new words" as a novel medium to explain prevailing thinking. The paper begins at "The End" since it is important for readers to understand that prevailing thinking tends to believe that public transport has no future. The new word auto-no-(e)motion is then presented so that readers can assess if a future of autonomous cars is likely; or perhaps "the emperor has no clothes." Next, the word non-o-sharing is introduced to help readers understand what I shall term the shared mobility lie. The paper then closes 
with a short outline of why public transport is the future of cities and presents the term transit fusion as a new way of explaining how developments in our past will enhance the future of public transport in cities.

Presenter: Graham Currie, Director, Public Transport Research Group (PTRG), Monash University, Australia

Recording and Handout: https://www.cutr.usf.edu/2018/04/cutr-webcast-avs-shared-mobility-andurban-transit-futures/

\section{To Predict with Confidence, Plan for Freedom}

April 26, 2018

What will urban transportation be like in 10-20 years? How will automated vehicles interact with social and cultural trends to define the city of tomorrow? Will the vehicles of the future be owned or shared? How will pricing evolve to motivate behavior? What will happen to public mass transit? What other innovations can we expect that will transform the landscape?

This presentation, which is merely the outline of a larger argument, suggests three interconnected answers:

- We can't possibly know. History has always been unpredictable, punctuated with shocks, but if the pace of change is accelerating, then unpredictability may be increasing too.

- We can reach many strong conclusions without knowing. A surprising number of facts about transportation, including some fairly counterintuitive insights that would be transformative if widely understood, can be described and justified solidly with little or no empirical ground, because they are matters of geometry and physics or of nearly axiomatic principles of biology.

- Prediction may not be what matters anyway. If we abandoned hope of predicting the future, we could still describe a compelling outcome of transportation investment, one that motivates many people who will never care about a ridership prediction or economic impact analysis. We could also predict it in the sense that we can predict the continued value of pi. That idea is freedom, as transportation expands or reduces it.

This presentation will discuss the main points of an article published in the Journal of Public Transportation.

Presenter: Jarrett Walker, Jarrett Walker + Associates

Recording and Handout: https://www.cutr.usf.edu/2018/04/cutr-webcast-to-predict-with-confidenceplan-for-freedom/

\section{Performance-Based Management and Operations of Transportation Systems: Curriculum Concepts}

May 9, 2018

The Federal Highway Administration has been supporting a project aimed at developing and preparing a fully annotated Model Curriculum on Performance-based Planning for Transportation Systems Management and Operations (TSMO) that can be used for undergraduate and graduate courses in Transportation Planning and/or Traffic Engineering. The curriculum has been developed as a series of 
eight modules with case studies and PowerPoint presentations that can easily be incorporated into both undergraduate and graduate courses. Join us for a quick introduction to the curriculum and hear from faculty members Dr. Stephanie Ivey (University of Memphis) and Dr. Mohammed Hadi (Florida International University) who have been incorporating TSMO components into their courses.

An Academic Curriculum that Inspires Future Transportation Professionals to Have a Broader Perspective on Managing and Operating Transportation Systems.

Webinar Outline

- Introduction of webinar (John Halkias/Jocelyn Bauer)

- Rationale for integrating performance-based management and operation of transportation systems into academic curricula. (Robert Bertini)

- Overview of the curriculum concept and modules (Mike Smith)

- Illustrative case studies to reinforce curriculum concepts. (Robert Bertini/Mike Smith)

- How an instructor can integrate these concepts into an undergraduate or graduate course (Stephanie Ivey/Robert Bertini/Mohamed Hadi)

- Review of curriculum brochure and outreach approach (Robert Bertini)

- Q\&A and comments from webinar participants (Open discussion)

- Closing comments (John Halkias)

Presenters: Dr. Stephanie Ivey, University of Memphis; Dr. Mohammed Hadi, Florida International University

Recording and Handout: https://www.cutr.usf.edu/2018/06/webinar-transportation-systemscurriculum-concepts/

\section{Airport Clean Vehicle Policies and Practices} May 10, 2018

This webcast will present the results of the Airport Cooperative Research Project Synthesis: "Clean Vehicles, Fuels, and Practices for Airport Private Ground Transportation Providers." The aim of this study was to research and summarize the experience of public-use airports with implementing airport clean vehicle policies for private ground transportation operators and identify major approaches, challenges, and best practices.

Presenters: Alexander Kolpakov and Austin Marie Sipiora, Center for Urban Transportation Research Recording and Handout: https://www.cutr.usf.edu/2018/05/cutr-webcast-airport-clean-vehiclepolicies-and-practices/

\section{Does the Future of Mobility Depend on Public Transportation?} May 15, 2018

We've all seen the headlines. "Will self-driving cars, taxis make mass transit obsolete?" (Davidson 2017) and "What happens if Uber or Lyft outcompetes public transit?" (Sen 2017) or even "Department Of Transportation Says The Future Of Transit Looks Pretty Bleak" (Griggs 2015). We are entering the next great revolution in how people move about in cities. But does the future of transportation mean the end of transit? 
This presentation will discuss the main points of an article published in the Journal of Public Transportation.

Presenter: Kari Watkins, Ph.D., Georgia Institute of Technology

Recording and Handout: https://www.cutr.usf.edu/2018/05/cutr-webcast-future-of-mobility-andautomated-and-connected-cars/

\section{Road Rage: Countering Vehicular Weaponization Through Urban Transportation Design Strategies}

May 24, 2018

This session focuses on what transportation administrators in the United States say they are doing to address and mitigate the threat of vehicular weaponization through planning decisions, public engagement, and networking with overlapping units of government. The presentation includes information on the past incidences of vehicular terrorism globally, an examination of ranges of approaches to the threat, as well as a critical examination of the effects of various approaches on urban life, walkability, and bikeability.

Presenters: Gerard C. Wellman, Ph.D., Associate Professor, Department of Politics \& Public Administration, California State University; and Josephine K. Hazelton, Graduate Student, California State University

Recording and Handout: https://www.cutr.usf.edu/webcast/archived-cutr-webcast-recordings/

\section{WalkWise Florida}

June 7, 2018

WalkWise Florida began in the Tampa Bay area in 2010 as "WalkWise Tampa Bay", a grassroots initiative funded by the Florida Department of Transportation, District 7 (Tampa Bay area). A few years later, several other Florida counties showed interest in providing this unique interactive community presentation. The program provides an informative, free 20-30 minute safety education presentation with time for discussion to anyone living or working in select Florida counties. The WalkWise presentation has been delivered to residents in 15 out of the 21 high priority counties in Florida since 2010. WalkWise Florida is managed by the Center for Urban Transportation Research (CUTR) at USF and funded by the Florida Department of Transportation.

Presenter: Jason Jackman, Center for Urban Transportation Research

Recording and Handout: https://www.cutr.usf.edu/2018/06/cutr-webcast-walkwise-florida/

\section{Transit in the 2000s: Where Does It Stand and Where Is It Headed?} June 21, 2018

U.S. public transit has experienced something of a renaissance in the 2000s, with per capita service levels increasing nationwide and public investment growing even faster-particularly expenditures on rail transit. Despite this expansion, overall transit patronage has been relatively flat, and has declined significantly since 2014. What is behind these trends, and what do they portend for the future of transit? In this paper we consider three challenges shaping transit today and in the years ahead: (1) the 
asymmetry of transit supply and use make it especially vulnerable to changes and disruptions; (2) many of the factors that determine transit ridership, such as levels of private vehicle ownership and use, are largely beyond the control of transit agencies; and (3) there remains no consensus about what purpose transit should serve-politically the industry thrives on the idea that it will reduce congestion or clean the air, while in practice it primarily moves poor people, a very different and sometimes conflicting role. How successfully transit systems manage each of these challenges will shape their future roles and significance.

This presentation will discuss the main points of an article published in the Journal of Public Transportation.

Presenters: Michael Manville, Brian D. Taylor, and Evelyn Blumenberg; UCLA Luskin School of Public Affairs

Recording and Handout: https://www.cutr.usf.edu/2018/06/cutr-webcast-transit-in-the-2000s/

\section{Overview of the Transit Capacity and Quality of Service Manual, 3rd Edition}

July 12,2018

The presentation will involve an overview of the $3^{\text {rd }}$ Edition of the Transit Capacity and Quality of Service Manual (TCQSM). This document over the past 20 years has been the authoritative reference related to transit capacity and level of service concepts and evaluation procedures, for both bus and rail modes, developed through the U.S. Transit Cooperative Research Program (TCRP). The structure of the overall document will be reviewed in the webinar, followed by some examples on how agencies have applied the document in addressing transit planning and design issues.

Presenter: Alan Danaher, P.E., PTOE, AICP, PTP, Assistant Vice President, Transit \& Rail Systems Group, WSP

Recording and Handout: https://www.cutr.usf.edu/2018/07/cutr-webcast-overview-of-the-transitcapacity-and-quality-of-service-manual/

\section{Is It Time for a Transit Renaissance? Navigating Travel Behavior, Technology, and Business Model Shifts in a Brave New World}

July 26, 2018

Travel behavior is undergoing a period of significant change in the United States. In 2016, public transit ridership fell in almost all major U.S. metropolitan regions. While Americans are still heavily dependent on the personal automobile for mobility, technological and societal changes are transforming how mobility is accomplished. This paper reviews the convergence of five trends leading to fundamental changes in public transportation: (1) changing generational behavior toward suburbanization and automobility; (2) new attitudes toward information communications technology; (3) shifting attitudes toward sharing and mobility on demand; (4) innovative alternatives to work and non-work travel; and (5) an increasing number of on-demand flexible route transportation options. The paper concludes with recommendations and guiding principles for public agencies to consider in responding to these trends.

This presentation will discuss the main points of an article published in the Journal of Public Transportation. 
Presenters: Susan Shaheen and Adam Cohen, University of California, Berkeley

Recording and Handout: https://www.cutr.usf.edu/2018/07/cutr-webcast-is-it-time-for-a-transitrenaissance/

Autonomous Vehicles: An Empirical Assessment of Consumers' Perceptions, Intended Adoption, and Impacts on Household Vehicle Ownership

August 2, 2018

Emerging automotive and transportation technologies have provided revolutionary possibilities in the way we might travel in the future. Major car manufacturers and technology giants have demonstrated significant progress in advancing and testing autonomous vehicles in real-life traffic conditions. Governmental agencies are grappling with how to plan transportation systems for a world with autonomous vehicles. Past research has shown that not all technologies are immediately welcomed by the public. Autonomous Vehicles would have to likely go through a similar phase, and would need to overcome not just technological challenges but also social barriers for successful penetration into the marketplace. The current webinar will describe in detail findings from a multi-population survey conducted in 2015 eliciting consumers' perceptions on autonomous vehicles, their intended adoption, and its impact on anticipated travel behavior.

In particular, attendees will learn about the potential market segments of autonomous vehicle consumers, their intentions to adopt this technology, their preferences and motivations for using shared autonomous vehicles, and the impacts of shared autonomous vehicles on household car ownership.

Presenter: Nikhil Menon, Postdoctoral Research Scholar, Center for Urban Transportation Research Recording and Handout: https://www.cutr.usf.edu/2018/08/cutr-webcast-autonomous-vehicles/

Operations and Planning for Connected Autonomous Vehicles: From Trajectory Control to Capacity Analysis

August 16, 2018

Increasing congestion, excessive fuel consumption and emissions, and unacceptable safety risks remain the major challenges to next-generation highway systems that are meant to be smart and sustainable. Advanced connected and automated vehicle (CAV) technologies offer unprecedented opportunities to smooth highway traffic and increase highway capacity. These technologies render the high possibility of precise control of intelligent vehicle trajectories in addition to passive accommodation of defective human drivers. We propose a shooting heuristic $(\mathrm{SH})$ approach that constructs smooth trajectories at the microscopic scale for a large number of interactive vehicles under realistic constraints (e.g., vehicle kinematic limits, traffic arrival conditions, car-following safety, and signal timing). SH has a very parsimonious structure (e.g., only four acceleration variables) and a very small computational complexity suitable for real-time applications. This SH technique has been applied to operations of both pure CAV traffic and mixed traffic in both freeway bottleneck and signalized arterial operations. Trajectory control is further integrated with signal optimization to further enhance the system performance. Numerical results show these trajectory control strategies can significantly reduce fuel consumption, travel delay and safety risks. 
Microscopic management will eventually impact macroscopic highway throughput. To facilitate infrastructure planning decisions, we propose an analytical capacity model for highway mixed traffic considering heterogeneous and stochastic headways in mixed traffic. This model captures not only the full spectrum of CAV market penetration rates but also all possible values of CAV platooning intensities that largely affect the spatial distribution of different headway types. Numerical experiments verify that this analytical model accurately quantifies the corresponding mixed traffic capacity at various settings. This analytical model allows for examination of the impact of different CAV technology scenarios on mixed traffic capacity. This analytical framework further enables us to build a compact lane management model to efficiently determine the optimal number of dedicated CAV lanes to maximize mixed traffic throughput of a multi-lane highway segment. This optimization model addresses varying demand levels, market penetration rates, platooning intensities and technology scenarios. Numerical analyses illustrate the application of this lane management model and draw insights into how the key parameters affect the optimal CAV lane solution and the corresponding optimal capacity. This model can serve as a useful and simple decision tool for near future CAV lane management and related planning decisions.

Presenter: Xiaopeng Li, Ph.D., Assistant Professor, Department of Civil and Environmental Engineering, University of South Florida

Recording and Handout: https://www.cutr.usf.edu/2018/08/cutr-webcast-operations-and-planning-forconnected-autonomous-vehicles/

\section{StarMetro's Pilot of a Mobile Fare Payment App}

August 28, 2018

This webcast will feature Sara Hendricks and Sean Barbeau, University of South Florida (USF), Tampa; and Kelly Robertson, BowStern LLC. StarMetro, the public transit agency in Tallahassee, Florida, piloted the use of a mobile fare payment app with over 300 volunteer transit riders. The test featured the use of Token Transit, an application for iOS and Android smartphones, which was configured to allow transit riders to choose from the full suite of bus fares offered by StarMetro, and pay via their smartphones. The app also allows riders to purchase bus fares for other riders, store bus fares on their phones and activate their bus pass before they board a StarMetro bus. The bus pass is visually validated by the bus operator. The pilot sought to determine gains in customer satisfaction resulting from the use of mobile fare payment, as well as operational efficiencies from the perspective of the bus operators. This pilot was phase II of a larger study sponsored by the Florida Department of Transportation (FDOT). Phase I reviewed several existing mobile fare payment systems and developed a concept of operations for use by Florida transit agencies as guidance for making investments in mobile fare payment technologies.

Presenters: Sean Barbeau, Ph.D. and Sara Hendricks, CUTR; and Kelly Robertson, BowStern

Recording and Handout: https://www.cutr.usf.edu/2018/08/cutr-webcast-starmetros-pilot-of-amobile-fare-payment-app/

\section{Motorcycle Safety Programs Using Public Health Approach}

August 30, 2018

Florida is one of the most beautiful states in which to ride a motorcycle, but motorcyclists in Florida are disproportionately vulnerable road users. Motorcyclists accounted for nearly $17 \%$ of all traffic fatalities 
in Florida in 2016, even though motorcycles account for only $3 \%$ of registered vehicles in Florida. This session will describe how the public health approach has been applied to motorcycle safety by the Motorcycle Injury Prevention team at the USF Center for Urban Transportation Research. In particular, examples of motorcycle safety programs that have been developed and implemented using well known public health theories and models will be shared in the session.

Presenter: Siwon Jang, Ph.D., Center for Urban Transportation Research

Recording and Handout: https://www.cutr.usf.edu/2018/08/cutr-webcast-motorcycle-safety-programsusing-public-health-approach/

\section{The Role of Public Transportation during a State of Emergency Declaration due to Natural Disasters}

September 13, 2018

Destructive natural disasters such as hurricanes or other extreme weather events challenge many industries, especially the public transit industry. The 2017 hurricane season proved to be tumultuous, with three major hurricanes devastating the U.S. in less than 2 months. The challenges faced in Florida, in response to Hurricane Irma, precipitated best practices and lessons learned related to monitoring and reporting status of transportation infrastructure, identifying temporary alternative solutions, and coordinating and communicating with Emergency Operations Centers, state Departments of Transportation, and individual transit agencies. Sharing the lessons learned from recent firsthand experiences will undoubtedly improve the public transit industry's emergency preparedness, response, and recovery activities.

Presenters: Jodi Godfrey and Roberta Yegidis, CUTR

Recording and Handout: https://www.cutr.usf.edu/2018/09/cutr-webcast-state-emergencydeclaration-due-to-natural-disasters/

\section{Media Framing of Fatal Bicyclist Crashes in Hillsborough County: A Critical Discourse Analysis September 27, 2018}

This research examines the linguistic choices that frame the relationships between bicyclists and other parties involved in fatal crash events. Textual data were collected via media reports of bicyclist traffic fatalities between January 2009 and June 2018 in Hillsborough County, Florida, which has a disproportionately high number of bicyclist and pedestrian deaths compared to other metropolitan areas of the United States. The reports were coded with qualitative data software for repeated textual features and analyzed using Norman Fairclough's procedure for critical discourse analysis (CDA), a rigorous qualitative method used to analyze both oral and written communication. The primary purpose of CDA in this study is to examine and critique common modes of discourse about bicyclist fatalities; through CDA, the researchers examine how linguistic choices produce meaning and reinforce the "common sense" or "taken for granted" lexicon of transportation. Coding categories, or "nodes," were created based on Fairclough's general categories of "experiential" and "expressive" codes. Experiential codes focus on vocabulary, words/wording, classifications, grammar, and sentence structure. Expressive codes center on the producer of the text's content, particularly related to the evaluation of subjects, identities, and outcomes. In addition to the content of language, Fairclough's method also draws attention to the general framing, or "schemata" of content. While episodic framing is used to report 
specific events and concrete circumstances, thematic framing presents news that accentuates political issues and events in some general context.

The results show that the majority of news reports were episodic rather than thematic, focusing on the traffic event and the parties involved in the crash, particularly the bicyclist. The vocabulary, grammatical structure, and narrative framing of the news reports largely functioned to remove blame from the motorist and to highlight the bicyclist's actions. The main strategies used to remove motorist agency and highlight bicyclist responsibility include nominalizations, passive sentences, and omission of motorist names or human identifiers. These linguistic strategies strengthen the perception that the responsibility for safety rests on the bicyclist and detracts attention from social policy reform that would lead to fewer bicyclist fatalities. A minority of articles written with thematic frames focused on larger issues such as social capital, safety and advocacy, and infrastructure. This interdisciplinary study is a unique contribution to transportation literature as it employs a methodology typically reserved for communication scholars and linguists; it identifies language as a site of power relationships and emphasizes language outcomes toward social change.

Presenters: Julie Bond and Erin Scheffels, Ph.D., CUTR

Recording and Handout: https://www.cutr.usf.edu/2018/09/cutr-webcast-media-framing-of-fatalbicyclist-crashes/

\section{Building an Alternative Fuel Bus Program: Funding Opportunities and Best Practices for Transit Agencies}

October 11, 2018

As part of the U.S. Department of Energy's Vehicle Technologies Office, Clean Cities coalitions foster the nation's economic, environmental, and energy security by working locally to advance affordable, domestic transportation fuels and technologies. Nearly 100 coalitions serve as the foundation of Clean Cities by working with community partners to implement alternative fuels and advanced vehicle technologies to transform local and regional transportation markets.

This webcast will feature a presentation from Tampa Bay Clean Cities Coalition on the coalition's efforts to expand alternative fuels use and funding opportunities that can be used to offset the cost of alternative fuel buses. The webcast will also feature a presentation from Pinellas Suncoast Transit Authority (PSTA) on the agency's efforts to develop an electric bus program. The presentation will include insights into the planning approaches, challenges, and best practices used to incorporate electric transit buses into an existing fleet. Download Handout

Presenters: Alexander Kolpakov and Austin Marie Sipiora, CUTR; and Jacob Labutka, PSTA

Recording and Handout: https://www.cutr.usf.edu/2018/10/cutr-webcast-building-alt-fuel-busprogram/

\section{Work Zone Crash Analysis in Florida}

October 24, 2018

During the maintenance and reconstruction of existing infrastructure and the construction of new infrastructure, designated work zones are important for the safety of road users and workers. These 
work zones are usually marked and managed by special traffic signs, standard channelizing devices, appropriate barriers, pavement markings, and construction vehicles. These special conditions of roadways require some level of monitoring by state and local enforcement for safe and efficient traffic operation. As such, driving conditions insider work zone require increased attention than the normal diving condition because of special conditions of construction, maintenance, and utility-work activities. Moreover, work zones also vary by its duration and types of work, which are not encountered on normal roadway system. With these unexpected driving conditions, work zone or construction areas very likely interrupt the expectancy of the drivers resulting in unexpected traffic delays, erratic maneuvers which results in safety concerns for overall traffic as well as for the workers. Considering the magnitude of the problem in terms of severity of work zone crashes, work zone is given significant emphasis in AASHTO Strategic Highway Safety Plan (SHSP). Appropriate traffic management is critical because it influences traffic delays, safety for motorists and workers, completion of roadwork in timely fashion as well as the maintenance of access to business and residents in the area. From the traffic operation and management perspective, as noted by Federal Highway Admiration (FHWA) study that work zone is likely to build traffic congestions that influences an increase in crash rates.

Nationally, fatal crashes and fatalities in work zone areas have increased over the year. With that trend, Florida had the 3rd highest number of fatal crashes in the nation, moving the 2nd highest in 2015 and 2016 according to the National Work Zone Safety Information Clearinghouse. Work zone statistics in the US for 2017 indicate that approximately 1 work zone crash per hour as opposed to 1 crash every 1.6 hours in 2014. As such, work-zone safety is considered one of the important emphasis areas in Florida's SHSP. Work zone safety and related injury severity have been the emphasis of a number of important research efforts over the years. This study intends to add to the body of knowledge by analyzing the characteristics of work zone crashes and the risk factors that lead to different severities in Florida using data from Florida's Crash Analysis Reporting System (CARS), including vehicle, roadway geometry, traffic volume, driver demographics, and spatial and temporal characteristics. This study will highlight the trend, crash characteristics and injury severity in Florida work zones from 2011 to 2017. With this analysis, this study also extends on the contributing factors that lead to different severity levels in work zone crashes over the time. Florida is expected to grow economically in terms of road infrastructure, work zones are likely to increase across the state with continued exposure to crash risks and injury severity. Given the importance of work zone safety in Florida and in the US, appropriate strategies and countermeasures need to be developed to reduce the frequency of crash and minimize the associated injury severity for all motorists and workers.

Presenter: Mouyid Islam, Ph.D. CUTR

Recording and Handout: https://www.cutr.usf.edu/2018/10/cutr-webcast-work-zone-crash-analysis-inflorida/

\section{Understanding Florida Transit Ridership Declines and How We Can Respond November 8, 2018}

This webinar will review findings from the exploration of Florida and National ridership declines and explore stakeholder strategies to respond.

Presenter: Steven Polzin, Ph.D., Program Director, Mobility Policy Research, Center for Urban Transportation Research 
Recording and Handout: https://www.cutr.usf.edu/2018/11/cutr-webcast-understanding-floridatransit-ridership-declines-and-how-we-can-respond/

\section{CUTR Transportation Webcasts}

\section{Development of Statewide Guidelines for Implementing Leading Pedestrian Intervals in Florida} March 14, 2019

Pedestrian safety is an ongoing major concern throughout the United States and is one of the highest priorities for the Florida Department of Transportation (FDOT). Vehicles often fail to yield to pedestrians at intersections, especially when pedestrians enter an intersection with a corresponding green signal in the same direction of vehicle travel. Leading Pedestrian Interval (LPI) has been implemented as a lowcost countermeasure to provide pedestrians an advance start before the concurrent green traffic signal to increase pedestrian visibility and safety in crosswalk. However, the LPI is not universally applied at all intersections since it is dependent on the characteristics of intersection geometry, vehicle and pedestrian traffic conditions, traffic signal timing, etc.

A comprehensive and integrated study sponsored by FDOT was conducted to determine the suitability and effectiveness of LPI implementation at signalized intersections to improve pedestrian safety and to develop robust guidelines for LPI implementation. This webcast will focus on the presentation of major project tasks and findings, LPI effectiveness, LPI warrants, illustrated examples, LPI implementation guidelines and recommendations. The research results and findings from this FDOT-sponsored project provide clear insights into the suitability of LPI implementation and its effectiveness in increasing pedestrian safety at signalized intersections, and also offer traffic engineers and managers a simple and robust tool for appropriate and effective LPI implementation.

Presenter: Pei-Sung Lin, Ph.D., P.E., PTOE, FITE, Program Director, ITS, Traffic Operations and Safety, Center for Urban Transportation Research

Recording and Handout: https://www.cutr.usf.edu/2019/03/cutr-webcast-leading-ped-intervals-fl/

Urban Roadway Facility Conversion with the Predictive Safety Assessment Tool: An Application of Highway Safety Manual

March 28, 2019

The impact of predictive safety assessment based on quantitative methodology of the Highway Safety Manual (HSM) is significant, particularly in urban roadway facilities. Realizing this significance, the responsibilities of safety professionals, transportation planners, and decision makers are critical for safe and efficient transportation in the ever-increasing travel demand in the urban areas. The purpose of this study was to develop a predictive safety assessment tool (PSAT) for converting one urban roadway facility type to another with the application of predictive methodology and principles from the HSM. This tool (PSAT) is intended to help safety professionals, transportation planners, and decision makers to evaluate safety effects considering the local conditions to make informed decisions in the planning process from the traffic safety perspective. This study focused on developing a proof-of-concept framework of PSAT for converting one facility to another with improvements to specific geometric elements in urban settings. By considering traffic exposure, existing geometric conditions, and unit length of corridor (i.e., one mile of corridor length), PSAT (MS Excel spreadsheet) enables the safety analysts to evaluate existing and proposed facilities and covers a wide range of urban roadway 
segments. Some examples include 2-lane undivided roadway; 2 lane roadway with two-way left-turn lane; 4-lane undivided and 4-lane divided roadway; 4-lane undivided roadway with two-way left-turn lane, 6-lane undivided lane, and 6-lane divided roadway; 6-lane undivided roadway with two left-turn lanes; and 8-lane divided roadway. The PSAT was developed with user-friendliness to help the safety analysts input values in color-coded areas within the recommended ranges for the parameters from the HSM. The output of the crash prediction and sensitivity analysis (i.e., impact of traffic volume on predicted crashes in comparison facilities of interest) were graphically displayed. Thus, PSAT displays a user-friendly dashboard for the safety analysts with a conversion factor and predicted crash frequency, distribution of collision types (i.e., single- and multi-vehicle collisions) by injury severity levels and impact of traffic volume as part of a sensitivity analysis based on the well-researched HSM methodology.

Presenter: Mouyid Islam, Ph.D. CUTR

Recording and Handout: https://www.cutr.usf.edu/2019/03/cutr-webcast-urban-roadway-facilityconversion/

\section{Control of Connected Autonomous Vehicles in Mixed Traffic: Modeling and Field Experiments} April 25, 2019

Advanced connected and automated vehicle (CAV) technologies can be utilized to achieve precise vehicle trajectory control and render unprecedented opportunities to improve transportation system performance in safety, mobility and sustainability. However, it is quite challenging to fully realize these advantages from CAV in mixed traffic environment due to stochastic and uncertain human-driven vehicle (HV) behavior. This study presents several key models for CAV control in both longitudinal and latitudinal directions considering coordination with infrastructure units (e.g., traffic signals) in mixed traffic environment. The fundamental idea of these models is to use learning based methods to estimate and predict HV behavior and use fast heuristic to plan and control the AV trajectory in a near-optimal manner. These models are validated with field experiments on a large-scale testbed in mixed traffic settings. These field studies are the first of its kind involving both longitudinal and latitudinal controls in mixed traffic. The results show that the proposed control models can safely and efficiently implement key AV control functions in mixed traffic.

Presenter: Xiaopeng Li, Ph.D., Assistant Professor, Department of Civil and Environmental Engineering, University of South Florida

Recording and Handout: https://www.cutr.usf.edu/2019/04/cutr-webcast-control-of-connectedautonomous-vehicles/

\section{Transit Stigma \& Social Equity: What Transportation Administrators Say They Are Doing About It} May 16, 2019

Services provided by public transportation agencies in the United States are crucial for personal mobility, maintaining and improving one's quality of life, and participation in the broader society. Societal goods like education, healthcare, employment, and cultural and civic opportunities are made possible by transit provision and decisions made by agency administrators. Thus it can be argued that public transport is necessary for connecting individuals, specifically the poor, to resources necessary for improving their quality of life and for pursuing urban social justice. 
But in many parts of the United States, including most mid-sized and small metropolitan areas, transit users are frequently stigmatized for lacking access to private automobiles. Many authors have documented transit's perceived role as the transport option for the poor, marginalized, and powerless. Simply put, in many places, public transportation is the wrong transportation.

Drawn from interviews with transit agency administrators from across the United States, this research finds that such administrators are vividly aware of transit stigma, actively working to dismantle it, and examining cutting-edge and controversial options. This webinar will examine their approaches, reflect on their insights, and critically examine their approaches to ending or mitigating transit stigma in their service area.

Presenters: Gerard C. Wellman, Ph.D., Associate Professor, Department of Politics \& Public Administration, California State University; and Josephine K. Hazelton, Doctoral Student, University of Nebraska at Omaha

Recording and Handout: https://www.cutr.usf.edu/2019/05/cutr-webcast-transit-stigma-social-equity/

\section{Development of Effective Truck Route Signing Program}

June 6, 2019

The City of Tampa, Florida, contains numerous major freight generators and destinations, including two seaports, a rail intermodal yard, the cargo-capable Tampa International Airport, and a wide variety of logistics activity centers. Effective and efficient transportation of commercial vehicles has become essential to the economy of Tampa Bay area. However, several communities in the Tampa Bay area have complained about the danger and noise of commercial trucks passing through their neighborhoods and not complying with existing truck route signage. To improve the safety, health, and quality of life in residential and/or non-truck route communities and improve the efficiency and mobility of commercial vehicles, compliance of commercial truck drivers with truck route signage at intersections is vital.

Traditionally, negative truck route signage has been used at intersections to prohibit commercial trucks from entering a specific roadway. In many cases, commercial truck drivers are unable to change lanes at the intersection to avoid entering a non-truck route because they did not see positive truck route signage to guide them in advance. An effective truck route signage program based on combined positive and negative truck route signage was developed for the City of Tampa via a successful pilot implementation. This pilot implementation demonstrated positive use of the roadway network, guided commercial truck drivers to drive on the designated truck route system, and significantly increased their compliance with the truck route signage.

In the pilot study, the CUTR project team conducted a detailed literature review to establish standards for sign types, sizes and locations for both positive and negative truck route signs and proposed locations for a pilot implementation. Based on truck route violations and complaints from communities, 8 study intersections with a total of 10 legs were selected for pilot implementation of proposed truck route signage, before-after data collection, and evaluation on the effectiveness of the proposed truck route signage. The quantitative analysis showed that there was an overall 56 percent reduction in the total number of commercial trucks using non-truck routes after the implementation of the combined positive and negative truck route signage at the 8 study sites. Specifically, it included 52 percent reduction in single-unit trucks, 69 percent reduction in tractor and semi-trailer combination trucks, and 
96 percent reduction in tractor and multi-trailer combination trucks. The statistical analysis indicated that these reductions are statistically significant at a $99 \%$ confidence level. This pilot study concluded that the implementation of combined positive and negative truck route signage could significantly increase commercial truck driver compliance with truck route signage to improve roadway safety and quality of life.

Presenter: Pei-Sung Lin, Ph.D., CUTR

Recording and Handout: https://www.cutr.usf.edu/2019/06/cutr-webcast-effective-truck-routesignage/

\section{Integrating Equity into MPO Project Prioritization}

June 20, 2019

This webinar discusses methods used by MPOs to prioritize projects based on equity, based on a study funded by the Center for Transportation, Equity, Decisions, \& Dollars (CTEDD). The webinar will examine how MPOs are selecting projects to provide communities of concern with greater access to opportunities, especially economic opportunity. The webinar elaborates on study findings from several case examples of MPO approaches relevant to equity in project prioritization. Representatives from two of the MPOs examined for the study, Sarasota-Manatee MPO and Boston Region MPO, will further discuss how they prioritize projects based on equity.

Presenters: Kristin Williams, Jeff Kramer, and Yaye Keita, CUTR

Recording and Handout: https://www.cutr.usf.edu/2019/06/cutr-webcastintegrating-equity-into-mpoproject-prioritization/

\section{Attracting and Retaining Women in the Transportation Industry} July 18, 2019

This session will summarize the findings and recommendations that stemmed from a recent publication out of the Mineta Transportation Institute on Attracting and Retaining Women in the Transportation Industry. The presenter will provide an overview of the current transportation setting, some findings as to why the industry struggles to attract a diverse workforce, and recommendations on how your agency can improve attraction and retention rates by encouraging inclusivity.

Presenter: Jodi Godfrey, CUTR

Recording and Handout: https://www.cutr.usf.edu/2019/07/webinar-attracting-and-retaining-womenin-the-transportation-industry/

How Transit Agencies Implement Best Practice Strategies in Complementary ADA Paratransit Eligibility

August 1, 2019

This session will summarize the findings and recommendations that stemmed from a recent publication out of the Journal of Public Transportation.

To encourage greater fixed route transit use for people with disabilities, transit agencies are implementing more rigorous paratransit eligibility determination practices. Previous studies identified 
best practice strategies for eligibility determination, but did not fully document the implementation of these strategies, nor the factors contributing to successes or challenges. This study interviewed 16 transit agencies across the United States to investigate the use of ADA complementary paratransit eligibility best practices in order to (a) determine the extent to which transit agencies are adopting suggested best practices as part of determining paratransit eligibility, (b) describe how agencies apply these strategies in daily operations, and (c) explore factors that contribute to implementation successes and challenges. Findings indicate that many transit agencies have incorporated multiple best practice eligibility strategies as part of department-wide changes in paratransit operations and have overcome implementation challenges by recognizing departmental limitations and collaborating with other departments and organizations.

Presenters: Molly Ranahan, PhD and Jordana Maisel, PhD, University of Buffalo

Recording and Handout: https://www.cutr.usf.edu/2019/08/webinar-complementary-ada-paratransiteligibility/

\section{Transportation that Will Transform Florida}

August 20, 2019

Senator Brandes looks forward to his webcast, where he will highlight current Florida legislation regarding autonomous and shared vehicles. He will explain the need for third-party validators in this field. Additionally, he will share some of our most exciting projects currently operating, as well as what he believes the future holds for this fascinating industry in the Great State of Florida.

Presenter: Senator Jeff Brandes

Recording and Handout: https://www.cutr.usf.edu/2019/08/cutr-webinar-transportation-that-willtransform-florida/

\section{Observations from the 2017 NHTS}

August 29, 2019

Understanding transit ridership and the characteristics of transit markets is a fundamental necessity for all individuals involved in planning, operating, marketing, and policy decision-making for public transit. The 2016 National Household Travel Survey (NHTS) data set was released in March of 2018, which affords researchers the ability to assess a range of public transit markets from multiple perspectives such as socio-demographics of transit markets, transit-specific trip characteristics, modal shares, etc. This webinar will review some of the trends of characteristics that affect or describe the public transit market in the U.S. using the NHTS data, while also comparing other datasets like the U.S. Census Bureau's American Community Survey, NTD, and APTA data to provide a holistic understanding of public transit in America. The objectives of this research are to afford transportation professionals, policy makers, and the public the data analyses necessary to form sound opinions and make judicious decisions regarding public transit.

Presenter: Jodi Godfrey, CUTR

Recording and Handout: https://www.cutr.usf.edu/2019/08/cutr-webcast-observations-from-2017nhts/ 


\section{Shared (Smart) Mobility, MaaS and Public Transport - A new Future!}

September 10, 2019

This talk focuses on Mobility as a Service (MaaS), and what it might mean for the future role of conventional public transport. We present evidence on potential user support for MaaS subscription plans and price points, as well some preliminary evidence on the interest by mobility and non-mobility providers in supplying assets or investing in a broker/aggregator platform to deliver a MaaS service. We also take a look at possible governance models as well as what this might mean for conventional public transport via a separate PAYGO platform. We also comment more generally on MaaS trials and the growing amount of hype and rhetoric surrounding MaaS. Is it likely to a mainstream or a niche product offering in the future?

Presenter: David Hensher, Professor of Management; Founding Director, Institute of Transport and Logistics Studies

Recording and Handout: https://www.cutr.usf.edu/2019/09/cutr-webinar-maas-and-public-transport-a$\underline{\text { new-future/ }}$

Transit and Livability: Results from the National Community Livability Survey

September 12, 2019

Presenter: Jeremy Mattson, NDSU

Recording and Handout: https://www.cutr.usf.edu/2019/09/cutr-webinartransit-and-livability-resultsfrom-the-national-community-livability-survey/

Opportunities for State DOTs (and others) to Encourage Shared-Use Mobility Practices in Rural Areas

September 26, 2019

Presenter: Ranjit Godavarthy, Ph.D., NDSU

Shared-use mobility (SUM) practices are transportation services that are shared among users. SUM can include 'traditional SUM' practices such as public transit, taxis, limousines, etc., or 'technology enabled SUM' (will be referred to as 'SUM' in this report) practices such as ridesourcing, carsharing, bikesharing, microtransit services, etc., While SUM practices exist in all size communities, their presence is much prominent in urban communities compared to rural communities.

While there exist significant mobility gaps in rural transit/transportation services due to low population densities and long travel distances in rural areas, SUM practices have the potential to fill the mobility gaps by offering fast, on-demand, and reliable transportation options. Many innovative SUM initiatives are being piloted and implemented in rural communities in conjunction with already-existing rural transit/transportation services and with business models tailored for rural communities. This study investigated various categories of SUM services such as ridesourcing, carsharing, bikesharing, and microtransit service's applicability in rural communities and determine the potential to supplement and/or compliment traditional rural transit/transportation services. 
One of the output of the study is a five-task rural SUM toolkit for strategies such as ridesourcing, carsharing, bikesharing, microtransit, as well as rural mobility as a service (MaaS) platforms. The rural SUM toolkit can inform state DOTs, regional transportation agencies, rural transit agencies, local governments, human service agencies, and other state and local agencies about the various steps and tasks involved for strategically planning to pilot and implement relevant SUM strategies to meet the unique transportation needs in rural communities. This toolkit can be applicable for small urban communities as well.

Recording and Handout: https://www.cutr.usf.edu/2019/09/cutr-webinar-state-dots-to-encourageshared-use-in-rural-areas/

\section{Florida Clean Cities Volkswagen Mitigation Plan}

October 15, 2019

Join the Florida Clean Cities Coalitions for a webcast on the Florida Volkswagen Environmental Mitigation Plan and funding opportunities. Attend this webinar to hear from the State's designated beneficiary, the Florida Department of Environmental Protection (DEP), and learn more about the Mitigation Plan and eligible projects. Representatives from Florida's Clean Cities Coalitions will present on tools and resources to prepare your organization for the next steps, and will discuss Plan implications for alternative fuel corridors. This webinar will also feature an interactive Q\&A session with technical experts to address specific questions on potential eligible projects, fuels, vehicle technologies, and infrastructure.

Presenters: Alexander Kolpakov, Tampa Bay Clean Cities/CUTR; JP Fraites, Florida Department of Environmental Protection; and Doug Kettles, Central Florida Clean Cities Coalition

Recording and Handout: https://www.cutr.usf.edu/2019/10/cutr-webinar-floridas-beneficiarymitigation-plan-webcast/

\section{Enhancing Cybersecurity in Public Transportation}

November 14, 2019

As transportation infrastructure continues to expand from isolated nodes to large interconnected networks, cybersecurity is a critical concern for transit agencies. This report provides recommendations and suggested policies for transit agencies that may help reduce cybersecurity liabilities. The recommendations are informed by a literature review of existing vulnerabilities, a survey of Florida transit agencies, a taxonomy of transit technologies, outcomes of cybersecurity working groups and workshops, and hands-on analyses of several technologies, all of which were conducted as part of this project. Existing vulnerabilities were discovered in literature for connected vehicles, autonomous vehicles, electronic ticketing systems, traffic signal controllers, traffic signal priority, and dynamic message signs. Survey participants ranked employee training as the biggest challenge to implementing good cybersecurity practices. The taxonomy of transit technologies was based on five dimensions: extent of deployment in Florida, mode of transportation, functionality, responsible organizations, and liabilities. The report also includes the results of the cybersecurity working group meetings and workshops held during the project and provides a detailed analysis of a vulnerability discovered in a Florida mobile fare payment application by the research team. Important areas of future work include further examining mobile fare payment apps, onboard Wi-Fi, and traffic controller equipment, as well as 
adding cybersecurity components to the existing management plan processes currently established for safety and security in Florida.

Presenters: Sean Barbeau, Ph.D., CUTR; Jarred Ligatti, USF

Recording and Handout: https://www.cutr.usf.edu/2019/11/cutr-webinar-enhancing-cybersecurity-inpublic-transportation/

\section{CUTR Transportation Webcasts}

\section{Smartphone Based Connected Bicycle Prototype Development for Sustainable Multimodal} Transportation System

January 30, 2020

The webinar will present the work completed towards the development of a prototype application for connected bicycles, that allows users to be safer in the future world of increasing connectivity between road users and infrastructure.

Presenter: Achilleas Kourtellis, Ph.D., CUTR

Recording and Handout: https://www.cutr.usf.edu/2020/01/cutr-webinar-smartphone-basedconnected-bicycle-prototype/

The Healthy Buddy Program: Addressing Immobility in Transportation-Disadvantaged Older Adults through a Community-Based Initiative

February 27, 2020

The webinar will present the community-based Healthy Buddy Program concept and its application for improving the mobility and quality of life among transportation-disadvantaged older adults. The webinar will discuss key qualitative interview findings from the first phase of the project, and provide an overview of the plan for implementation of the project in its current and upcoming phases.

Presenter: Siwon Jang, Ph.D, CUTR

Recording and Handout: https://www.cutr.usf.edu/2020/02/cutr-webinar-the-healthy-buddy-program/

Florida's Public Transit and Women's Safety - Real and Perceived Concerns

April 2, 20202

This webinar summarizes a study that examined issues of women's safety and security on public transit. The research conducted for the study indicates that there are shortcomings in addressing gender-based harassment on public transit and, more generally, in public spaces. Transit agencies tend to follow the current norm of treating harassment of women as a problem of individuals, rather than a problem in society of how women are treated. The study also included case study discussions with three transit agencies in Florida that provided insight into the agencies' awareness of gender-based harassment and the types of initiatives that are being implemented to address the safety and security of all passengers and workers. Additional focus on the unique needs of women traveling in public space can pay off in terms of higher ridership, as well. In society, women should not have to simply accept that they will be the targets of gender-based harassment or worse. Transit agencies are in a unique position as public 
entities to lead the way in addressing gender-based harassment, not only by addressing incidents on their services, but by engaging with their communities to address these issues on a larger, societal scale.

Presenter: Victoria Perk, Ph.D., CUTR

Recording and Handout: https://www.cutr.usf.edu/2020/04/cutr-webinar-floridas-public-transit-andwomens-safety/

\section{Campus Automated Shuttle Service Deployment Initiative}

April 9, 2020

Most mid-size and large open-campus universities, theme parks, commercial campuses, airports, and other low-speed environments have courtesy shuttle or bus service as an important mode of transportation around campus and in nearby vicinities. Given the nature of short-distance trips within or around campus, and difficulty with finding parking spaces, low-speed automated shuttle service has been recognized as a promising solution to alleviate these problems. In the past couple of years, the demonstration or testing of autonomous shuttles has begun to draw attentions in the US.

The University of South Florida (USF) is a major US university with approximately 50,000 students enrolled. For a successful deployment of autonomous shuttles on USF Tampa campus in the future, a demonstration and introduction of autonomous shuttles to students, faculty, and staff that allows them to have actual riding experience are valuable and essential.

This webinar will present a week-long campus automated shuttle demonstration held on the USF Tampa Campus in February 2019. The demonstration environment was of a dynamic nature with the automated shuttle maneuvering through pedestrians, bicyclists, and skateboarders along a wide walkway. The webinar will share many findings from the onboard opinion survey of $500+$ shuttle riders and field observation of the shuttle operations during the demonstration. The onboard survey results showed an overwhelmingly positive attitude towards participants' rider experience during the demonstration, and indicated their willingness to use these automated shuttles as a mode for travel on campus. The results also showed the potential for autonomous shuttle to replace some campus trips currently undertaken via other modes. The onboard survey indicated a growing user trust when exposed to automated vehicles and their subsequent ride in the shuttle. The field observation showed the capability of an automated shuttle to gradually adjust its speed and direction when the shuttle faced with the prospect of interacting with road users. The shuttle was able to take passive action and avoid conflicts with other road users. From field observation, there were also instances where the shuttle executed evasive movement due to safety reasons. In addition to the survey results and field observations, the webinar will also provide some recommendations for future demonstrations in this arena.

This automated shuttle demonstration on the USF Tampa Campus, in which respondents were exposed to new/emerging technologies, can serve as important benchmarks to assess the progression of public opinion and preferences towards the autonomous shuttle and autonomous vehicle technologies in a rapidly-evolving world.

Presenter: Pei-Sung Lin, Ph.D., CUTR 
Recording and Handout: https://www.cutr.usf.edu/2020/03/cutr-webinar-campus-automated-shuttleservice-deployment-initiative/

\section{Improving the Quality and Cost Effectiveness of Multimodal Travel Behavior Data Collection} April 22, 2020

Multimodal transportation such as transit, bike, walk, transportation network companies (TNCs) (e.g., Uber, Lyft), car share, and bike share are vital to supporting livable communities. However, current data collection techniques for multimodal travel behavior, including apps built specifically for travel behavior surveys, have limitations (e.g., significant negative impact on battery life, user acquisition) which prevent a better understanding of significant real-world challenges (e.g., multimodal traveler choices, relationships between travel behavior and health).

This webinar discusses the results of a recently completed research project funded by the National Center for Transit Research, "Improving the Quality and Cost Effectiveness of Multimodal Travel Behavior Data Collection". In this project, the research team developed and deployed a proof-ofconcept system to collect multimodal travel behavior data on an ongoing basis directly from users of a popular open-source mobile app for multi-modal information, OneBusAway (OBA). To overcome battery life challenges, the research team used the Android Activity Transition API, which leverages hardware advancements in modern mobile phones.

This webinar presents the technology used to implement this data collection tool, as well as the results of a pilot deployment to 676 beta testing users. Over 10 weeks, 74 users opted into the study without any incentive and contributed 65,582 trips. Key concerns discussed for data collection when conserving battery life include the timeliness and accuracy of data.

Presenter: Sean Barbeau, Ph.D., CUTR

Recording and Handout: https://www.cutr.usf.edu/2020/04/cutr-webinar-improving-the-quality-andcost-effectiveness-of-multimodal/ 


\section{Appendix B: Webinar Advertisements}

\section{Email Announcement}

Sample eblast announcements to the CUTR distribution list in MailChimp.

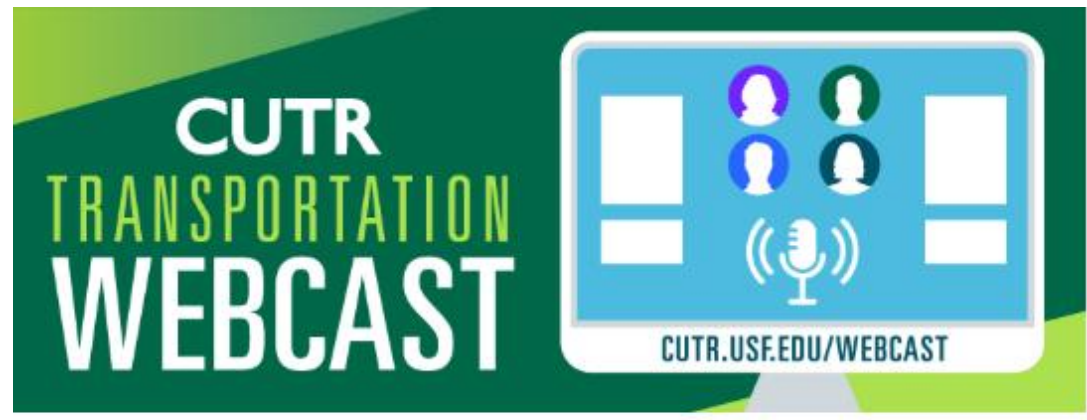

The Healthy Buddy Program:

Addressing Immobility in

Transportation-Disadvantaged Older Adults through a Community-Based Initiative

Thursday, February 27, 2020, 12:00PM (ET)

The webinar will presented by SiWon Jang, Ph.D., Center for Urban Transportation Research. The focus of this session will be on the community-based Healthy Buddy Program concept and its application for improving the mobility and quality of life among transportation-disadvantaged older adults. The webinar will discuss key

qualitative interview findings from the first phase of the project, and provide an overview of the plan for implementation of the project in its current and upcoming phases.

\section{Learn More}

\section{Topic Submission}

Have a question, submit a topic or recommend a speaker by sending an email to Stephanie Lewis.
Recently Recorded

October 15, 2019

Florida Clean Cities

Volkswagen Mitigation Plan Alexander Kolpakov, Tampa Bay Clean Cities/CUTR; JP Fraites, Florida Department of Environmental Protection; and Doug Kettles, Central Florida Clean Cities Coalition

November 14, 2020 Enhancing Cybersecurity in

Public Transportation Sean Barbeau, Ph.D., CUTR, Kevin Dennis and Jarred Ligatti, USF

January 30, 2020

Smartphone-based Connected Bicycle Prototype Development for a Safer Multimodal Transportation System

Achilieas Kourtellis, Ph. D. Center for Urban

Transportation Research

Recorded Webinars

Upcoming

Webinars

The complete list of all upcoming CUTR

Transportation Webcasts. 


\section{Social Media Posts}

\section{Facebook Post}

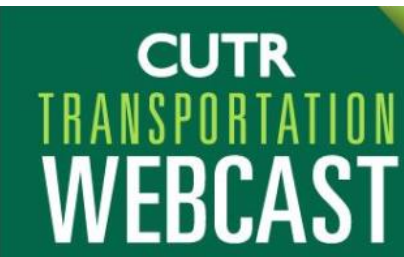

$\square$ September 26, 2019

() 12:00PM (ET)

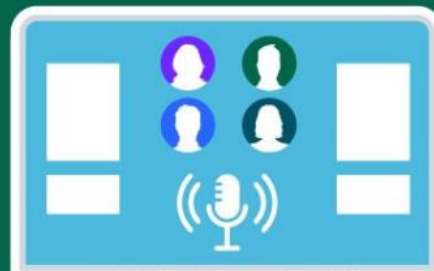

CUTR.USF.EDU/WEBCAST
Opportunities for State DOTs (and others) to Encourage Shared-Use Mobility Practices in Rural Areas
CUTR

Please join us for a FREE CUTR Transportation Webcast "Opportunities for State DOTs (and others) to Encourage Shared-Use Mobility Practices in Rural Areas" today from 12pm to $1 \mathrm{pm}$ (ET). Presented by Ranjit Godavarthy, Ph. D. Assistant Professor, North Dakota State University.

https://www cutr ust edu/2019/09/cutr-webinar-statedots-to-encourage-shared-use-in-rural-areas/

Rebecca Liller, Mouyid Islam and Babak Mirzazadeh like this

Ranjit Godavarthy, Ph.D. Small Urban and Rural Transit Cente North Dakota State University

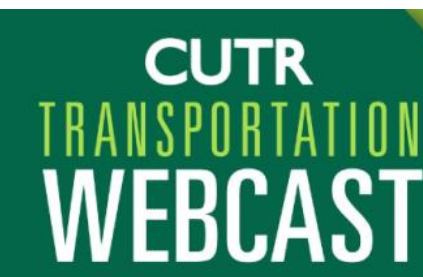

$\square$ May 16, 2019

() $12: 00 P M(E T)$

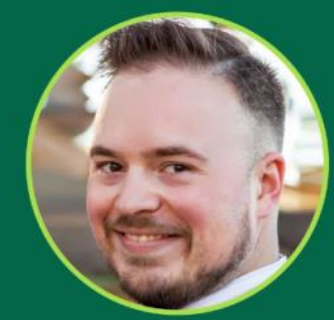

Gerard C. Wellman, Ph.D. California State University
Transit Stigma \& Social Equity: What Transportation Administrators Say They Are Doing About It
Josephine K. Hazelton University of Nebraska
CUTR Center for Urban Transportation Research - CUTR

Please join us for a FREE CUTR Transportation Webcast Transit Stigma \& Social Equity. What Transportation Aaministrators Say They Are Doing by Gerard C Wellman Ph D. Associate Professor, Department of Poilitics \& Public Administration. California State University, and Josephine $K$ Hazelton, Doctoral Student, University of Nebraska

https / / www cutr usf edu/2019/04/cutr-webcasttransit-stigma-socia 


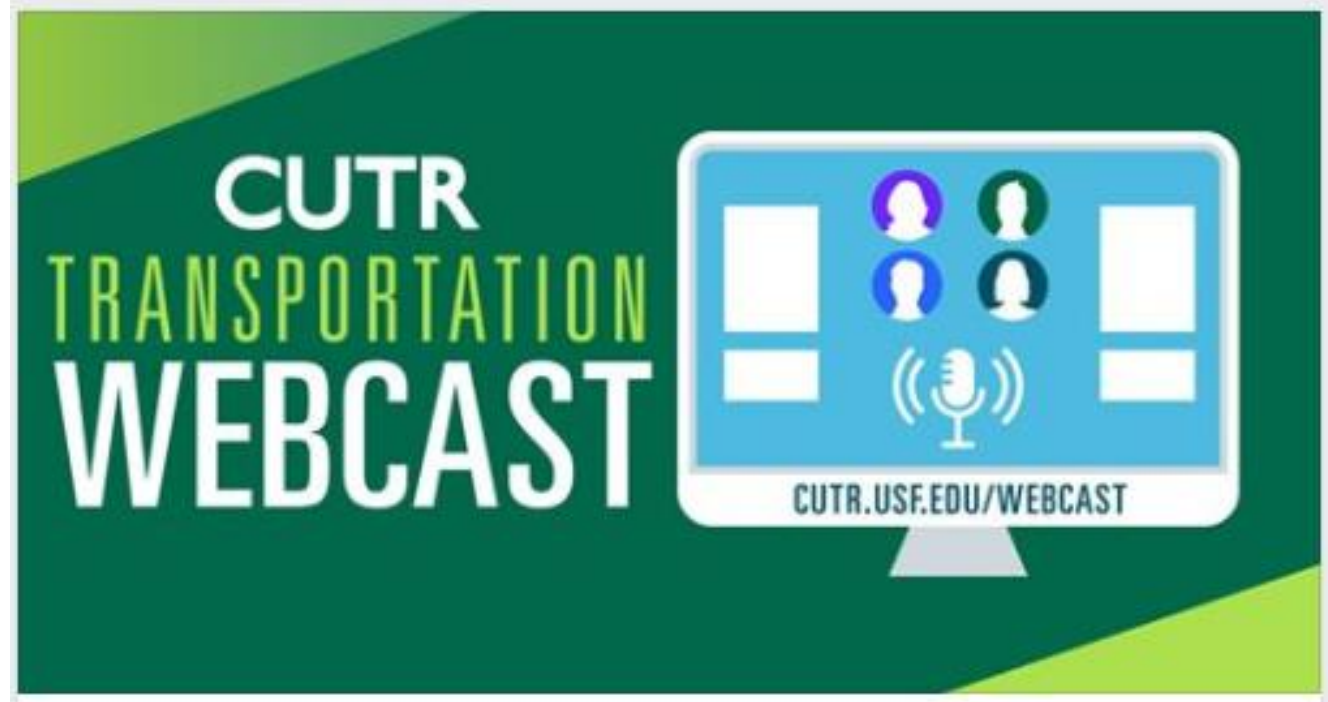

ост Webinar: Florida Clean Cities Volkswagen

15 Mitigation Plan

Public - Hosted by Center for Urban Transportation Research CUTR

$\star$ Interested $\quad \checkmark$ Going

(1) Tuesday, October 15,2019 at 12 PM - 1 PM about 8 months ago

- Center for Urban Transportation Research - CUTR 3808 USF Alumni Drive, CUT100, Tampa, Florida 33620 


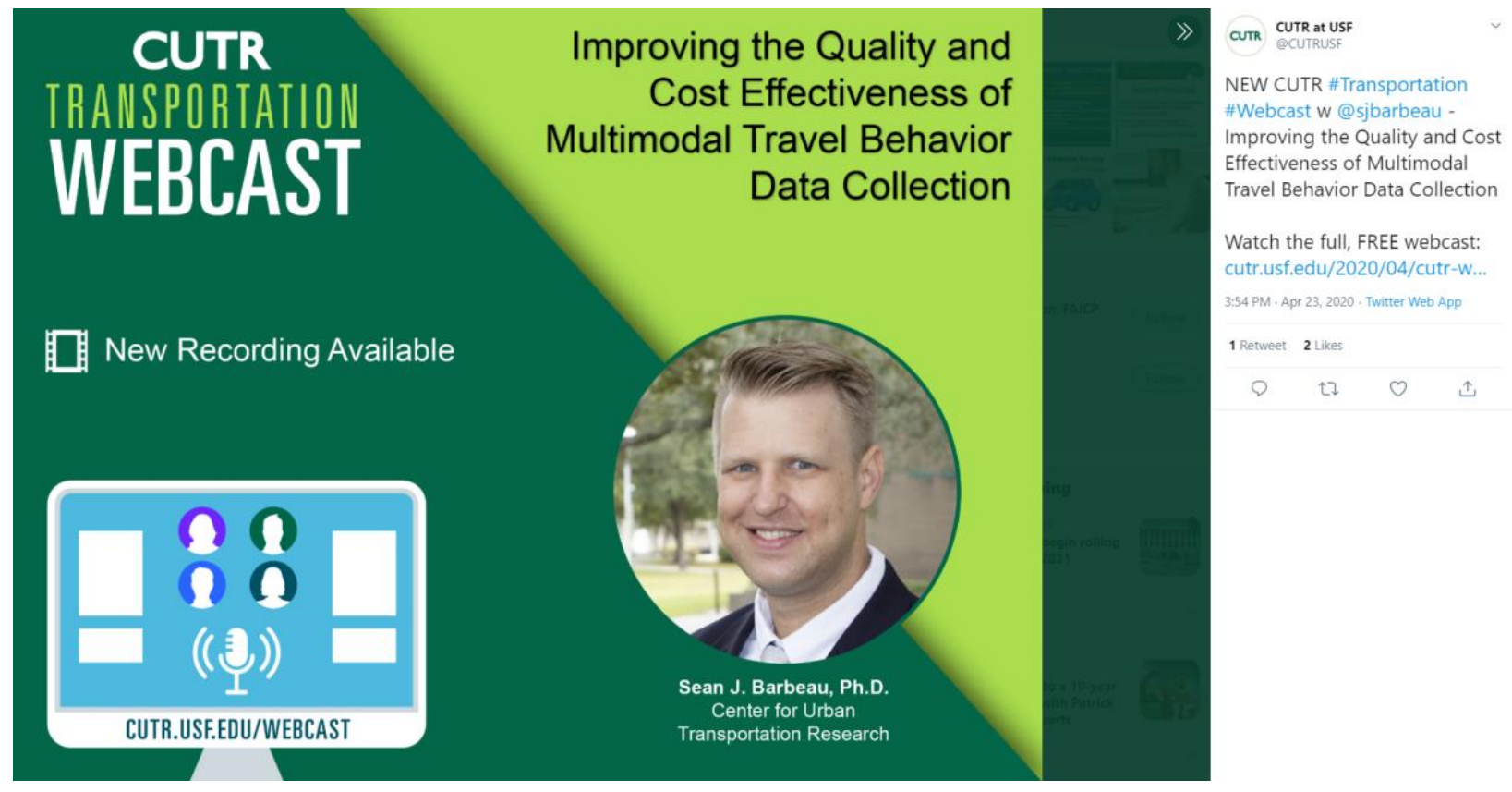




\section{Appendix C: Webinar Views}

\begin{tabular}{|c|c|c|c|c|}
\hline Date & Title & Presenter(s) & $\begin{array}{l}\text { Live } \\
\text { Views }\end{array}$ & $\begin{array}{l}\text { Recorded } \\
\text { Views }\end{array}$ \\
\hline $3 / 29 / 18$ & $\begin{array}{l}\text { Trends in Travel Behavior } \\
\text { and Transit Ridership }\end{array}$ & $\begin{array}{l}\text { Steven Polzin, Ph.D., Program } \\
\text { Director, Mobility Policy } \\
\text { Research, Center for Urban } \\
\text { Transportation Research }\end{array}$ & 105 & 261 \\
\hline $4 / 12 / 18$ & $\begin{array}{l}\text { Understanding the Effects } \\
\text { of Demographic and Socio- } \\
\text { Economic Factors on Public } \\
\text { Transit Ridership Trends }\end{array}$ & $\begin{array}{l}\text { Kurt Lehmann, Graduate } \\
\text { Research Assistant, Center for } \\
\text { Urban Transportation Research }\end{array}$ & 51 & 167 \\
\hline $4 / 18 / 18$ & $\begin{array}{l}\text { Lies, Damned Lies, AV's, } \\
\text { Shared Mobility, and Urban } \\
\text { Transit Futures }\end{array}$ & $\begin{array}{l}\text { Graham Currie, Director, Public } \\
\text { Transport Research Group } \\
\text { (PTRG), Monash University, } \\
\text { Australia }\end{array}$ & 43 & 529 \\
\hline $4 / 26 / 18$ & $\begin{array}{l}\text { To Predict with Confidence, } \\
\text { Plan for Freedom }\end{array}$ & $\begin{array}{l}\text { Jarrett Walker, Jarrett Walker + } \\
\text { Associates }\end{array}$ & 80 & 201 \\
\hline $5 / 9 / 18$ & $\begin{array}{l}\text { Performance-Based } \\
\text { Management and } \\
\text { Operations of } \\
\text { Transportation Systems: } \\
\text { Curriculum Concepts }\end{array}$ & $\begin{array}{l}\text { Dr. Stephanie Ivey, University of } \\
\text { Memphis; Dr. Mohammed Hadi, } \\
\text { Florida International University }\end{array}$ & 91 & 89 \\
\hline $5 / 10 / 18$ & $\begin{array}{l}\text { Airport Clean Vehicle } \\
\text { Policies and Practices }\end{array}$ & $\begin{array}{l}\text { Alexander Kolpakov and Austin } \\
\text { Marie Sipiora, Center for Urban } \\
\text { Transportation Research }\end{array}$ & 10 & 20 \\
\hline $5 / 15 / 18$ & $\begin{array}{l}\text { Does the Future of Mobility } \\
\text { Depend on Public } \\
\text { Transportation? }\end{array}$ & $\begin{array}{l}\text { Kari Watkins, Ph.D., Georgia } \\
\text { Institute of Technology }\end{array}$ & 78 & 106 \\
\hline $5 / 24 / 18$ & $\begin{array}{l}\text { Road Rage: Countering } \\
\text { Vehicular Weaponization } \\
\text { Through Urban } \\
\text { Transportation Design } \\
\text { Strategies }\end{array}$ & $\begin{array}{l}\text { Gerard C. Wellman, Ph.D., } \\
\text { Associate Professor, } \\
\text { Department of Politics \& Public } \\
\text { Administration, California State } \\
\text { University; and Josephine K. } \\
\text { Hazelton, Graduate Student, } \\
\text { California State University }\end{array}$ & 45 & 40 \\
\hline $6 / 7 / 18$ & WalkWise Florida & $\begin{array}{l}\text { Jason Jackman, Center for Urban } \\
\text { Transportation Research }\end{array}$ & 16 & 53 \\
\hline $6 / 21 / 18$ & $\begin{array}{l}\text { Transit in the 2000s: Where } \\
\text { Does It Stand and Where Is } \\
\text { It Headed? }\end{array}$ & $\begin{array}{l}\text { Michael Manville, Brian D. } \\
\text { Taylor, and Evelyn Blumenberg; } \\
\text { UCLA Luskin School of Public } \\
\text { Affairs }\end{array}$ & 48 & 45 \\
\hline $7 / 21 / 18$ & $\begin{array}{l}\text { Overview of the Transit } \\
\text { Capacity and Quality of } \\
\text { Service Manual, 3rd Edition }\end{array}$ & $\begin{array}{l}\text { Alan Danaher, P.E., PTOE, AICP, } \\
\text { PTP, Assistant Vice President, } \\
\text { Transit \& Rail Systems Group, } \\
\text { WSP }\end{array}$ & 27 & 35 \\
\hline
\end{tabular}




\begin{tabular}{|c|c|c|c|c|}
\hline Date & Title & Presenter(s) & $\begin{array}{l}\text { Live } \\
\text { Views }\end{array}$ & $\begin{array}{l}\text { Recorded } \\
\text { Views }\end{array}$ \\
\hline $7 / 26 / 18$ & $\begin{array}{l}\text { Is It Time for a Transit } \\
\text { Renaissance?: Navigating } \\
\text { Travel Behavior, } \\
\text { Technology, and Business } \\
\text { Model Shifts in a Brave } \\
\text { New World }\end{array}$ & $\begin{array}{l}\text { Susan Shaheen and Adam } \\
\text { Cohen, University of California, } \\
\text { Berkeley }\end{array}$ & 91 & 53 \\
\hline $8 / 2 / 18$ & $\begin{array}{l}\text { Autonomous Vehicles: An } \\
\text { Empirical Assessment of } \\
\text { Consumers' Perceptions, } \\
\text { Intended Adoption, and } \\
\text { Impacts on Household } \\
\text { Vehicle Ownership }\end{array}$ & $\begin{array}{l}\text { Nikhil Menon, Postdoctoral } \\
\text { Research Scholar, Center for } \\
\text { Urban Transportation Research }\end{array}$ & 39 & 92 \\
\hline $8 / 16 / 18$ & $\begin{array}{l}\text { Operations and Planning } \\
\text { for Connected Autonomous } \\
\text { Vehicles: From Trajectory } \\
\text { Control to Capacity } \\
\text { Analysis }\end{array}$ & $\begin{array}{l}\text { Xiaopeng Li, Ph.D., Assistant } \\
\text { Professor, Department of Civil } \\
\text { and Environmental Engineering, } \\
\text { University of South Florida }\end{array}$ & 34 & 40 \\
\hline $8 / 28 / 18$ & $\begin{array}{l}\text { StarMetro's Pilot of a } \\
\text { Mobile Fare Payment App }\end{array}$ & $\begin{array}{l}\text { Sean Barbeau, Ph.D. and Sara } \\
\text { Hendricks, CUTR; and Kelly } \\
\text { Robertson, BowStern }\end{array}$ & 49 & 50 \\
\hline $8 / 30 / 18$ & $\begin{array}{l}\text { Motorcycle Safety } \\
\text { Programs Using Public } \\
\text { Health Approach }\end{array}$ & $\begin{array}{l}\text { Siwon Jang, Ph.D., Center for } \\
\text { Urban Transportation Research }\end{array}$ & 33 & 62 \\
\hline $9 / 13 / 18$ & $\begin{array}{l}\text { The Role of Public } \\
\text { Transportation during a } \\
\text { State of Emergency } \\
\text { Declaration due to Natural } \\
\text { Disasters }\end{array}$ & $\begin{array}{l}\text { Jodi Godfrey and Roberta } \\
\text { Yegidis, CUTR }\end{array}$ & 52 & 142 \\
\hline $9 / 27 / 18$ & $\begin{array}{l}\text { Media Framing of Fatal } \\
\text { Bicyclist Crashes in } \\
\text { Hillsborough County: A } \\
\text { Critical Discourse Analysis }\end{array}$ & $\begin{array}{l}\text { Julie Bond and Erin Scheffels, } \\
\text { Ph.D., CUTR }\end{array}$ & 60 & 339 \\
\hline $10 / 11 / 18$ & $\begin{array}{l}\text { Building an Alternative Fuel } \\
\text { Bus Program: Funding } \\
\text { Opportunities and Best } \\
\text { Practices for Transit } \\
\text { Agencies }\end{array}$ & $\begin{array}{l}\text { Alexander Kolpakov and Austin } \\
\text { Marie Sipiora, CUTR; and Jacob } \\
\text { Labutka, PSTA }\end{array}$ & 42 & 66 \\
\hline $10 / 24 / 18$ & $\begin{array}{l}\text { Work Zone Crash Analysis } \\
\text { in Florida }\end{array}$ & Mouyid Islam, Ph.D. CUTR & 11 & 70 \\
\hline $11 / 8 / 18$ & $\begin{array}{l}\text { Understanding Florida } \\
\text { Transit Ridership Declines } \\
\text { and How We Can Respond }\end{array}$ & $\begin{array}{l}\text { Steven Polzin, Ph.D., Program } \\
\text { Director, Mobility Policy } \\
\text { Research, Center for Urban } \\
\text { Transportation Research }\end{array}$ & 60 & 141 \\
\hline
\end{tabular}




\begin{tabular}{|c|c|c|c|c|}
\hline Date & Title & Presenter(s) & $\begin{array}{l}\text { Live } \\
\text { Views }\end{array}$ & $\begin{array}{l}\text { Recorded } \\
\text { Views }\end{array}$ \\
\hline $3 / 14 / 19$ & $\begin{array}{l}\text { Development of Statewide } \\
\text { Guidelines for } \\
\text { Implementing Leading } \\
\text { Pedestrian Intervals in } \\
\text { Florida }\end{array}$ & $\begin{array}{l}\text { Pei-Sung Lin, Ph.D., P.E., PTOE, } \\
\text { FITE, Program Director, ITS, } \\
\text { Traffic Operations and Safety, } \\
\text { Center for Urban Transportation } \\
\text { Research }\end{array}$ & 22 & 128 \\
\hline $3 / 28 / 19$ & $\begin{array}{l}\text { Urban Roadway Facility } \\
\text { Conversion with the } \\
\text { Predictive Safety } \\
\text { Assessment Tool: An } \\
\text { Application of Highway } \\
\text { Safety Manual }\end{array}$ & Mouyid Islam, Ph.D. CUTR & 16 & 33 \\
\hline $4 / 25 / 19$ & $\begin{array}{l}\text { Control of Connected } \\
\text { Autonomous Vehicles in } \\
\text { Mixed Traffic: Modeling } \\
\text { and Field Experiments }\end{array}$ & $\begin{array}{l}\text { Xiaopeng Li, Ph.D., Assistant } \\
\text { Professor, Department of Civil } \\
\text { and Environmental Engineering, } \\
\text { University of South Florida }\end{array}$ & 39 & 36 \\
\hline $5 / 16 / 19$ & $\begin{array}{l}\text { Transit Stigma \& Social } \\
\text { Equity: What } \\
\text { Transportation } \\
\text { Administrators Say They } \\
\text { Are Doing About It }\end{array}$ & $\begin{array}{l}\text { Gerard C. Wellman, Ph.D., } \\
\text { Associate Professor, } \\
\text { Department of Politics \& Public } \\
\text { Administration, California State } \\
\text { University; and Josephine K. } \\
\text { Hazelton, Doctoral Student, } \\
\text { University of Nebraska at } \\
\text { Omaha }\end{array}$ & 51 & 60 \\
\hline $6 / 6 / 19$ & $\begin{array}{l}\text { Development of an } \\
\text { Effective Truck Route } \\
\text { Signing Program }\end{array}$ & Pei-Sung Lin, Ph.D., CUTR & 7 & 15 \\
\hline $6 / 20 / 19$ & $\begin{array}{l}\text { Integrating Equity in MPO } \\
\text { Project Prioritization }\end{array}$ & $\begin{array}{l}\text { Kristin Williams, Jeff Kramer, } \\
\text { and Yaye Keita, CUTR }\end{array}$ & 38 & 73 \\
\hline $7 / 18 / 19$ & $\begin{array}{l}\text { Attracting and Retaining } \\
\text { Women in the } \\
\text { Transportation Industry }\end{array}$ & Jodi Godfrey, CUTR & 65 & 96 \\
\hline $8 / 1 / 19$ & $\begin{array}{l}\text { How Transit Agencies } \\
\text { Implement Best Practice } \\
\text { Strategies in } \\
\text { Complementary ADA } \\
\text { Paratransit Eligibility }\end{array}$ & $\begin{array}{l}\text { Molly Ranahan, PhD and } \\
\text { Jordana Maisel, PhD, University } \\
\text { of Buffalo }\end{array}$ & 45 & 105 \\
\hline $8 / 20 / 19$ & $\begin{array}{l}\text { Transportation that Will } \\
\text { Transform Florida }\end{array}$ & Senator Jeff Brandes & 51 & 84 \\
\hline $8 / 29 / 19$ & $\begin{array}{l}\text { Observations from the } \\
2017 \text { NHTS }\end{array}$ & Jodi Godfrey, CUTR & 39 & 35 \\
\hline $\begin{array}{l}\text { 9/10/19@ } \\
7 p m(E T)\end{array}$ & $\begin{array}{l}\text { Shared (Smart) Mobility, } \\
\text { MaaS and Public Transport } \\
\text { - A new Future! }\end{array}$ & $\begin{array}{l}\text { David Hensher, Ph.D., Professor } \\
\text { of Management; Founding } \\
\text { Director, Institute of Transport } \\
\text { and Logistics Studies }\end{array}$ & 12 & 95 \\
\hline
\end{tabular}




\begin{tabular}{|c|c|c|c|c|}
\hline Date & Title & Presenter(s) & $\begin{array}{l}\text { Live } \\
\text { Views }\end{array}$ & $\begin{array}{l}\text { Recorded } \\
\text { Views }\end{array}$ \\
\hline 9/12/19 & $\begin{array}{l}\text { Transit and Livability: } \\
\text { Results from the National } \\
\text { Community Livability } \\
\text { Survey }\end{array}$ & Jeremy Mattson, NDSU & 26 & 17 \\
\hline $9 / 26 / 19$ & $\begin{array}{l}\text { Shared Use Mobility in } \\
\text { Rural Areas }\end{array}$ & Ranjit Godavarthy, Ph.D., NDSU & 54 & 119 \\
\hline $10 / 15 / 19$ & $\begin{array}{l}\text { Florida Clean Cities } \\
\text { Volkswagen Mitigation Plan }\end{array}$ & $\begin{array}{l}\text { Alexander Kolpakov, Tampa Bay } \\
\text { Clean Cities/CUTR; JP Fraites, } \\
\text { Florida Department of } \\
\text { Environmental Protection; and } \\
\text { Doug Kettles, Central Florida } \\
\text { Clean Cities Coalition }\end{array}$ & 85 & 25 \\
\hline $11 / 14 / 19$ & $\begin{array}{l}\text { Enhancing Cybersecurity in } \\
\text { Public Transportation }\end{array}$ & $\begin{array}{l}\text { Sean Barbeau, Ph.D., CUTR; } \\
\text { Jarred Ligatti, USF }\end{array}$ & 18 & 42 \\
\hline $1 / 30 / 20$ & $\begin{array}{l}\text { Smartphone Based } \\
\text { Connected Bicycle } \\
\text { Prototype Development for } \\
\text { Sustainable Multimodal } \\
\text { Transportation System }\end{array}$ & Achilleas Kourtellis, Ph.D., CUTR & 30 & 25 \\
\hline $2 / 27 / 20$ & $\begin{array}{l}\text { The Healthy Buddy } \\
\text { Program: Addressing } \\
\text { Immobility in } \\
\text { Transportation- } \\
\text { Disadvantaged Older } \\
\text { Adults through a } \\
\text { Community-Based Initiative }\end{array}$ & Si Won Jang, Ph.D., CUTR & 22 & 29 \\
\hline $4 / 2 / 20$ & $\begin{array}{l}\text { Florida's Public Transit and } \\
\text { Women's Safety - Real and } \\
\text { Perceived Concerns }\end{array}$ & Victoria Perk, Ph.D., CUTR & 4 & 70 \\
\hline $4 / 9 / 20$ & $\begin{array}{l}\text { Campus Automated Shuttle } \\
\text { Service Deployment } \\
\text { Initiative }\end{array}$ & Pei-Sung Lin, Ph.D., CUTR & 6 & 0 \\
\hline $4 / 22 / 20$ & $\begin{array}{l}\text { Improving the Quality and } \\
\text { Cost Effectiveness of } \\
\text { Multimodal Travel Behavior } \\
\text { Data Collection }\end{array}$ & Sean Barbeau, Ph.D., CUTR & 5 & 85 \\
\hline & & SUBTOTAL & 1,700 & 3,773 \\
\hline & & TOTAL & \multicolumn{2}{|c|}{5,473} \\
\hline
\end{tabular}

